

Oviedo-Mireles JC et al. (2021)

Notulae Botanicae Horti Agrobotanici Cluj-Napoca

Volume 49, Issue 3, Article number 12409

DOI: $10.15835 /$ nbha49312409

Research Article

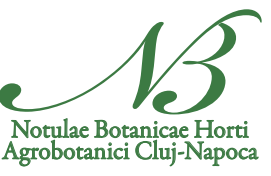

\title{
Salicylic acid and nutrient immersion to maintain apple quality and bioactive compounds in postharvest
}

\author{
Julio C. OVIEDO-MIRELES ${ }^{1}$, Juan M. SOTO-PARRA ${ }^{1 *}$, \\ Esteban SÁNCHEZ², Rosa M. YÁÑEZ-MUÑOZ1, \\ Ramona PÉREZ-LEAL ${ }^{1}$, Linda C. NOPERI-MOSQUEDA ${ }^{1}$ \\ ${ }^{1}$ Universidad Autónoma de Chihuahua, Facultad de Ciencias Agrotecnológicas, Universidad Campus 1, C.P. 31530, Chihuahua, \\ México; juceoviedo@hotmail.com; jmsotoparra@gmail.com (*corresponding author); \\ rosky1388@gmail.com;perezleal@hotmail.com;lnoperi@uach.mx \\ ${ }^{2}$ Centro de Investigación en Alimentación y Desarrollo A.C. Unidad Delicias, C.P. 33088, Chihuahua, México; esteban@ciad.mx
}

\begin{abstract}
The world production of apples in the 2019 cycle reached 7'620,288 tonnes. For marketing purposes and to supply the demand, apple fruits need to be stored for different periods under refrigerated conditions. However, in the market, the shelf life of the fruit is short, the quality decreases in postharvest due to the dynamic changes of its physicochemical properties, which cannot be stopped, but can be slowed down to improve its shelf life. Postharvest treatments by immersing apple fruit in salicylic acid (SA) and nutrients are an innovative technological alternative to maintain their quality. In this study, 5 concentrations were tested for the immersion of apple fruits cv 'Golden Delicious', using a 56 factorial arrangement delimited to 25 treatments, using the Taguchi L25 structure: SA $0-1.440 \mathrm{mM}$, potassium $(\mathrm{K}) 0-2.250$, calcium $(\mathrm{Ca}) 0$ $31.500 \mathrm{mM}$, cobalt (Co) $0-0.180 \mathrm{mM}$, molybdenum (Mo) $0-0.0900 \mathrm{mM}$ and magnesium $(\mathrm{Mg}) 0-0.0900$ $\mathrm{mM}$. The study was conducted in the municipality of Cuauhtémoc, Chihuahua, Mexico. After 7 months of storage and 13 days of shelf life, the combination of $\mathrm{K}, \mathrm{Ca}, \mathrm{SA}$ and $\mathrm{Co}$ with the appropriate concentration values can maintain the quality variables and bioactive compounds at the desired optimum. It is concluded that the quality variables; firmness, juice percentage, juice density, titratable acidity and total soluble solids and the bioactive compounds; total phenols and antioxidant capacity can be maintained at the desired optimum.
\end{abstract}

Keywords: controlled atmosphere; chilling; factors; Malus domestica; postharvest

\section{Introduction}

World apple production in the 2019 cycle reached 7'620,288 tonnes. Mexico contributed 761,483 t (FAO, 2020). To supply the demand, apple fruits need to be stored under refrigerated conditions and different periods for marketing purposes (Cepeda et al., 2014). Postharvest changes in fresh fruit cannot be stopped, but they can be slowed down to improve shelf life. Postharvest treatments play an important role in extending the storage and shelf life of perishable horticultural products (El-Ramady et al., 2018).

Pre-storage treatments through immersion of fruits in Ca (Conway et al., 2002), SA (Supapvanich, 2015) and Mg with Ca (Farag and Nagy, 2012) in postharvest, emerge as a technological and innovative Received: 23 Jun 2021. Received in revised form: 17 Sep 2021. Accepted: 20 Sep 2021. Published online: 24 Sep 2021. From Volume 49, Issue 1, 2021, Notulae Botanicae Horti Agrobotanici Cluj-Napoca journal uses article numbers in place of the traditional method of continuous pagination through the volume. The journal will continue to appear quarterly, as before, with four annual numbers. 
alternative to maintain quality in apples. Quality is considered as a dynamic synthesis of physicochemical properties of fruits, and has been boosted by advances in postharvest physiology and technology (Kyriacou and Rouphael, 2017). Agricultural and postharvest practices contribute to flavour, and it is believed that the flavour quality of many fresh fruits available to consumers has deteriorated (Bartoshuk and Klee, 2013).

An important decision to ensure high fruit quality is the time of harvest. Early or late harvesting can lead to several negative aspects that decrease fruit quality (Vanoli and Buccheri, 2012). The degree of fruit ripening influences the production of volatile flavour compounds during storage and shows that harvesting too early or too late can negatively affect fruit yield and flavour development (Salas-Salazar et al., 2011). Within the same orchard, variability among trees can influence final product quality, with fruit load and distribution levels being important, which can severely affect fruit quality and maturity (Serra et al., 2016).

In the market, the shelf life of apples is short, due to their flimsy skin, moisture loss and high sensitivity to chilling. Physical damage to the skin of the fruit such as shrinkage of the top of the fruit, pitting, brown spots and rotting are the main problems that limit its acceptability for consumption and shelf life (Supapvanich et al., 2018). The characteristics that determine apple quality can be measured or graded (Musacchi and Serra, 2018). Consumers initially evaluate the fruit by its external appearance and then by its internal characteristics that give it its eating quality, although the latter can determine whether a customer buys the product again.

The relationship between apple tree nutrition and fruit quality is important, just as the proper balance of nutrients is essential to maintain fruit quality and shelf life. Fruit colour, size, bitter pit, internal breakdown, and watery core are often the commercially important attributes that fruit growers wish to predict. SA and among the nutrients $\mathrm{Ca}, \mathrm{K}, \mathrm{Mg}$, Co and $\mathrm{Mo}$, are considered to have the most notable influence (Casero et al., 2004).

SA, as a plant hormone is considered a safe compound for postharvest use (Asghari and Aghdam, 2010). It's used to maintain postharvest quality and delay fruit ripening (Supapvanich and Promyou. 2013). In addition, SA can strengthen fruit tissue structure by maintaining the pectin structure (Promyou and Supapvancih, 2016). In wax apple (Supapvanich et al., 2018) showed that immersion in SA at a concentration of $0.5 \mathrm{mM}$, flesh firmness was maintained, and antioxidant activity and certain secondary metabolites were increased during storage.

$\mathrm{Ca}$ and $\mathrm{K}$ are important in the water balance, $\mathrm{Ca}$ forms part of the cell membrane and is stored between the cell wall and the middle sheet, where it interacts with peptidic acid to form calcium pectate, providing stability for its integrity. Equally important, it intervenes in the regulation of enzyme systems and phytohormone activity, increasing tissue resistance to pathogens, as well as postharvest shelf life and nutritional quality (Yfran et al., 2017). Cepeda-Castañeda et al. (2014), reported that immersions of apples in $4 \% \mathrm{CaCl}_{2}$ increase $\mathrm{Ca}$ content, which favours the delay of firmness and weight loss, allowing fruit storage. $\mathrm{K}$ influences the permeability of cell membranes and tissue hydration, due to its high mobility in the phloem and xylem, it is important in the transport of solutes, the distribution of assimilates, and the synthesis of polyphenols responsible for colour and aroma. Besides, $\mathrm{K}$ positively affects the size, firmness, total soluble solids (TSS), juiciness and is very important for fruit storage (Brunetto et al., 2016). Conversely, its deficiency reduces fruit acidity, causes poor colouring, small fruit, and low organic acids (Musacchi and Serra, 2018).

$\mathrm{Mg}$ is a bivalent cation as $\mathrm{Ca}^{2+}$ and is likely to be bound between pectic substances within the cell wall or bound between polar heads in the plasma membrane. Therefore, it may maintain the integrity of the cell wall and plasma membrane (Farag and Nagy, 2012). Some apple cultivars, such as 'Golden Delicious' are very susceptible to $\mathrm{Mg}$ deficiency, as it can reduce productivity and fruit quality.

$\mathrm{Co}^{2+}$ ion is an inhibitor of the ethylene biosynthesis pathway (Lau and Yang, 1976). Few enzymes contain Mo, it acts as an enzyme co-factor, has both structural and catalytic functions and has direct implications in redox reactions (Nautiyal and Chatterjee, 2004).

Previous work has been done on the application and dosage of SA and nutrients in post-harvest immersion (Supapvanich et al. 2018). Their use can be a safe and reliable alternative. However, there is little information on their combined application in apple. Therefore, the aim of this work was to evaluate the effects 
of SA and nutrient immersion in combination to maintain the quality and improve bioactive compounds of apple cv 'Golden Delicious' during postharvest storage.

\section{Materials and Methods}

\section{Experimental area and treatments}

The research work was carried out in the 2018 cycle. It was carried out in the orchard and cold storage plant "La Campana", owned by Mr. Abram Olfert, located in the Mennonite field number 22 in the municipality of Cuauhtémoc, Chihuahua, Mexico, with an average altitude of 2048 meters above sea level, North latitude $28^{\circ} 26^{\prime} 17.5^{\prime \prime}$ and West longitude $106^{\circ} 53^{\prime} 40.3^{\prime \prime}$. Finishing and fruit quality analyses were carried out in the soil laboratory of the Faculty of Agrotechnological Sciences of the Universidad Autónoma de Chihuahua.

A 56-factorial arrangement with 5 concentrations and 6 factors was used (Table 1). The experiment was limited to 25 treatments in the Taguchi L25 structure (Table 2) with four replicates.

Table 1. Factors and application levels of the Taguchi L25 structure

\begin{tabular}{|c|c|c|c|c|c|c|}
\hline \multirow{2}{*}{ Levels } & \multicolumn{7}{|c|}{ Factors mM } \\
\cline { 2 - 7 } & $\mathrm{K}$ & $\mathrm{Ca}$ & Co & Mo & SA & $\mathrm{Mg}$ \\
\hline 0 & 0.0000 & 0.000 & 0.000 & 0.0000 & 0.000 & 0.0000 \\
\hline 1 & 0.1125 & 1.575 & 0.009 & 0.0045 & 0.072 & 0.0045 \\
\hline 5 & 0.5625 & 7.875 & 0.045 & 0.0225 & 0.360 & 0.0225 \\
\hline 10 & 1.1250 & 15.750 & 0.090 & 0.0450 & 0.720 & 0.0450 \\
\hline 20 & 2.2500 & 31.500 & 0.180 & 0.0900 & 1.440 & 0.0900 \\
\hline Simple average & 1.1250 & 15.750 & 0.090 & 0.045 & 0.720 & 0.0450 \\
\hline Stock solution mM & 300 & 500 & 50 & 100 & 4.5 & 50 \\
\hline
\end{tabular}

Sources: Fainal $\mathrm{K}^{\mathrm{MR}}(\mathrm{K}, 46.5 \%)$; $\mathrm{CaCl}_{2}$ (Ca, 36.11\%); $\mathrm{CoCl}_{2}$ (Co, 24.8\%), Prosimol ${ }^{\mathrm{MR}}$ (Mo, 39.0\%); salicylic acid (SA, 99.7\%) and $\mathrm{MgSO}_{4}(\mathrm{Mg}, 16.3 \%)$

For the selection of apple fruit at harvest, special care was taken in the field to obtain 32 fruits of commercial quality per treatment, without any physical damage or visible diseases. For each treatment, $5 \mathrm{~L}$ of water were added to a $20 \mathrm{~L}$ container, the amounts of stock solution indicated in Table 2 were added, and the solution was made up to $10 \mathrm{~L}$ by adding water and shaking. The 32 fruits were immersed and shaken manually for $10 \mathrm{~min}$. At the end of this time, they were removed and left at room temperature for $5 \mathrm{~min}$ to drain the excess water. They were then placed in perforated plastic bags in groups of 8 for each repetition, for storage in a controlled atmosphere for a period of 7 months.

Once the storage process was finished, the fruits were taken to the laboratory and kept at room temperature to simulate the shelf life. The quality of the fruits was evaluated 1, 5,9 and 13 days after harvest, using 5 fruits for each repetition to obtain colour, firmness, total soluble solids (TSS), juice density, juice percentage and titratable acidity (TA). The remaining 3 fruits were used to determine the biological compounds: total phenols (TF) and antioxidant capacity (AC). 
Table 2. Treatments formed in Taguchi $\mathrm{L} 25$ structure, $\mathrm{mL}$ of stock solution application, for dives apple

\begin{tabular}{|c|c|c|c|c|c|c|}
\hline Treatment & Fainal K & $\mathrm{CaCl}_{2}$ & $\mathrm{CoCl}_{2}$ & Prosimol & SA & $\mathrm{MgSO}_{4}$ \\
\hline 1 & 0.0000 & 0.000 & 0.000 & 0.0000 & 0.000 & 0.0000 \\
\hline 2 & 0.0000 & 1.575 & 0.009 & 0.0045 & 0.072 & 0.0045 \\
\hline 3 & 0.0000 & 7.875 & 0.045 & 0.0225 & 0.360 & 0.0225 \\
\hline 4 & 0.0000 & 15.750 & 0.090 & 0.0450 & 0.720 & 0.0450 \\
\hline 5 & 0.0000 & 31.500 & 0.180 & 0.0900 & 1.440 & 0.0900 \\
\hline 6 & 0.1125 & 0.000 & 0.009 & 0.0225 & 0.720 & 0.0900 \\
\hline 7 & 0.1125 & 1.575 & 0.045 & 0.0450 & 1.440 & 0.0000 \\
\hline 8 & 0.1125 & 7.875 & 0.090 & 0.0900 & 0.000 & 0.0045 \\
\hline 9 & 0.1125 & 15.750 & 0.180 & 0.0000 & 0.072 & 0.0225 \\
\hline 10 & 0.1125 & 31.500 & 0.000 & 0.0045 & 0.360 & 0.0450 \\
\hline 11 & 0.5625 & 0.000 & 0.045 & 0.0900 & 0.072 & 0.0450 \\
\hline 12 & 0.5625 & 1.575 & 0.090 & 0.0000 & 0.360 & 0.0900 \\
\hline 13 & 0.5625 & 7.875 & 0.180 & 0.0045 & 0.720 & 0.0000 \\
\hline 14 & 0.5625 & 15.750 & 0.000 & 0.0225 & 1.440 & 0.0045 \\
\hline 15 & 0.5625 & 31.500 & 0.009 & 0.0450 & 0.000 & 0.0225 \\
\hline 16 & 1.1250 & 0.000 & 0.090 & 0.0045 & 1.440 & 0.0225 \\
\hline 17 & 1.1250 & 1.575 & 0.180 & 0.0225 & 0.000 & 0.0450 \\
\hline 18 & 1.1250 & 7.875 & 0.000 & 0.0450 & 0.072 & 0.0900 \\
\hline 19 & 1.1250 & 15.750 & 0.009 & 0.0900 & 0.360 & 0.0000 \\
\hline 20 & 1.1250 & 31.500 & 0.045 & 0.0000 & 0.720 & 0.0045 \\
\hline 21 & 2.2500 & 0.000 & 0.180 & 0.0450 & 0.360 & 0.0045 \\
\hline 22 & 2.2500 & 1.575 & 0.000 & 0.0900 & 0.720 & 0.0225 \\
\hline 23 & 2.2500 & 7.875 & 0.009 & 0.0000 & 1.440 & 0.0450 \\
\hline 24 & 2.2500 & 15.750 & 0.045 & 0.0045 & 0.000 & 0.0900 \\
\hline 25 & 2.2500 & 31.500 & 0.090 & 0.0225 & 0.072 & 0.0000 \\
\hline
\end{tabular}

Each treatment was volumetrically diluted with water to $10 \mathrm{~L}$ of solution.

\section{Fruit quality}

To obtain colour in percentage (\%), the scale developed by Soto et al. (2001) was used. Two measures of colour per fruit, being two intermediates in terms of colour, considering six categories for 'Golden Delicious': 1) green; 2) rough green rough lenticels; 3) waxy green; 4) transition to yellow; 5) whitish yellow (yellowish); and 6) strongly yellow with a tendency towards orange. The colour scale was expressed as a percentage.

Fruit firmness was determined with a Wilson FTB 327 hand-held penetrometer with a capacity of 0 to $29 \mathrm{lb} \mathrm{in}^{-2}$, with an $11 \mathrm{~mm}$ plunger. Two readings were taken on the sides where the colour was measured, the peel was removed for measurement and the two readings were averaged.

For the determination of TSS in ${ }^{\circ}$ Brix, a Red Rooster 90681 refractometer was used, with a scale of 0.0 to $32.0^{\circ}$ Brix. Two segments were extracted from each fruit (one for each pressure test), weighed and taken to the juice extractor, and a few drops of the sample obtained were deposited on the prism of the refractometer previously calibrated with distilled water. The extract obtained was poured into a graduated cylinder. It was left to stand until phase separation was observed and the volume of juice and bagasse was quantified. The juice density or juiciness $\mathrm{g} \mathrm{ml}^{-1}$ and the percentage of juice were obtained.

The titratable acidity in \% malic acid was obtained using $10 \mathrm{~mL}$ of the same juice used to obtain TSS, 6 drops of $1 \%$ phenolphthalein were added, and a titration was made with $0.1 \mathrm{~N}$ sodium hydroxide, until a brick pink colour was obtained. The volume used was converted to its equivalent of malic acid.

The TSS/titratable acidity ratio was determined on the basis of SS and malic acid. 


\section{Bioactive compounds}

Total phenols were determined according to the technique of Singleton and Rossi (1965), with slight modifications, using gallic acid as a standard. A quantity of $2 \mathrm{~g}$ of apple pulp was ground and extracted with 20 $\mathrm{ml}$ of $80 \%$ methanol. $750 \mu \mathrm{l}$ of $2 \%$ sodium carbonate, $250 \mu \mathrm{l}$ of $50 \%$ Folin-Ciocalteau, $1375 \mu \mathrm{l}$ of distilled water and $250 \mu \mathrm{l}$ of the pulp extract was placed in a test tube. Vortexed and left to react for $60 \mathrm{~min}$ in the dark at room temperature. The absorbance was measured at $725 \mathrm{~nm}$ in a DR $5000 \mathrm{Hach}$ visible spectrophotometer. Results were expressed as g gallic acid per $\mathrm{g}$ fresh weight $\left(\mathrm{g} \mathrm{GA} \mathrm{g}^{-1}\right)$. A calibration curve was plotted. Linearity was determined between 0.5 and $2.0 \mathrm{mg} \mathrm{ml}^{-1}$, using a high purity reagent grade gallic acid standard, the calibration was measured in triplicate, the value of the equation was $6.2228 \mathrm{x}-0.0107$, with an $\mathrm{r}^{2}$ of 0.9804 .

For antioxidant capacity analysis according to the methodology of Brand-Williams et al. (1995), with slight modifications. $2.8 \mathrm{ml}$ of freshly prepared $0.1 \mathrm{mM} \mathrm{DPPH}$ solution $(3.94 \mathrm{mg}$ DPPH in $100 \mathrm{ml} 80 \%$ methanol) was added to a test tube, $0.2 \mathrm{ml}$ supernatant of the homogenate used for the determination of total phenols was added, vortexed and allowed to react for $60 \mathrm{~min}$ in the dark at room temperature. The absorbance was measured at $517 \mathrm{~nm}$, using a DR 5000 Hach visible spectrophotometer. As a blank, 80\% methanol was substituted for the extract and a capacity curve was plotted. Linearity was determined between 0 and $600 \mathrm{M}$ using high purity reagent grade Trolox as standard, the calibration was measured in triplicate. The equation had a value of $0.0008 x+0.6984$ with an $r^{2}$ of 0.9855 . The analyses were measured in triplicate. Results were expressed as mg Trolox $\mathrm{g}^{-1}$ fresh weight.

\section{Statistical analysis}

Given the Taguchi L25 factorial structure for the generation of the treatments, the statistical analysis was performed by linear and full quadratic response surface, adjusting the surface to determine the levels of the factors for optimal response. A response surface was estimated by least squares regression using the SAS statistical package (SAS Institute Inc., SAS/STAT Software: Usage and Reference, Version 6, First Edition, Cary, NC: SAS Institute Inc., 1989). The analysis for each response variable included three stages: 1) analysis of the regression and the contribution of each factor to the regression fit; 2) canonical analysis of the response surface to determine the shape of the curve for those factors that had significant linear, quadratic and interaction responses; and 3) the predicted values depending on whether the minimum or maximum response was selected according to the original range of the data. The behaviour of all response variables was summarised in a table where the factors and the simple average for each of them were specified. The resulting eigenvalues expressed as percentages of the mean are taken as positive or negative, as appropriate. The contribution of the eigenvectors was expressed with rounded signs so that $0.3750 \leq++\leq 0.6249,0.6250 \leq+++\leq 0.8749,++++$ $>0.8750$. The same procedure was applied to the negative eigenvalues. In this way, the factors were weighted to determine which have the most influence on each variable. Data were analysed for each of the four dates assessed.

\section{Results and Discussion}

Table 3 shows the result of the statistical analysis at the first day of shelf life, with the frequency of signs for the eigenvectors present. Table 4 shows the selection of factors and variables on the first day of shelf life. The results show that the most important factors selected were; SA (35), Ca (35) and K (30). While the variables selected were; juice percentage (23), AC (20) and firmness (19). The selection was also carried out for 5, 9 and 13 days, the results are shown in Tables $S 1$ to $S 6$. 
Table 3. Factors, fruit quality and bioactive compounds of apple, stored in a controlled atmosphere for 7 months and left on the shelf for 1 day

\begin{tabular}{|c|c|c|c|c|c|c|c|c|}
\hline \multirow[b]{2}{*}{ Eigenvalues } & \multicolumn{6}{|c|}{ Factors / simple average [mM] } & & \\
\hline & $\begin{array}{c}\mathrm{K} \\
1.125^{\mathrm{s}}\end{array}$ & $\begin{array}{c}\mathrm{Ca} \\
15.75\end{array}$ & $\begin{array}{c}\text { Co } \\
\mathbf{0 . 0 9 0}\end{array}$ & $\begin{array}{c}\text { Mo } \\
0.045\end{array}$ & $\begin{array}{c}\text { SA } \\
0.720\end{array}$ & $\begin{array}{c}\mathrm{Mg} \\
0.045\end{array}$ & \multicolumn{2}{|c|}{$\begin{array}{l}\text { Eigenvectors } \\
\text { Total Prop. +/- }\end{array}$} \\
\hline & \multicolumn{6}{|c|}{ Colour $^{\mathrm{U}} \mu 60.00(56.88-62.92 \%) \mathrm{R}^{2} 0.7681 \quad$ C.V. 4.67} & & \\
\hline $20.38^{\mathrm{T}}$ & $-\mathrm{C}^{\mathrm{V}}$ & +++ & & & & & 5 & $3 / 2$ \\
\hline-7.52 & ++ & ++ & --- & & & & 7 & $4 / 3$ \\
\hline-21.19 & ++ & & & & +++ & & 5 & $5 / 0$ \\
\hline Freq. & $6^{\mathrm{W}}$ & 5 & 3 & 0 & 3 & 0 & $17^{\mathrm{Y}}$ & $12 / 5$ \\
\hline$[\mathrm{mM}]^{\mathrm{X}}$ & & & & & & & \multicolumn{2}{|c|}{ Selection $\geq 3$} \\
\hline & \multicolumn{6}{|c|}{ Firmness $\mu 10.65\left(9.38-12.05 \mathrm{lb}^{2} \mathrm{in}^{2}\right) \mathrm{R}^{2} 0.9192 \quad$ C.V. 6.23} & & \\
\hline 45.18 & +++ & & & & -- & & 5 & $3 / 2$ \\
\hline 18.56 & & +++ & & & ++ & -- & 7 & $5 / 2$ \\
\hline-19.15 & & +++ & ++ & & & ++ & 7 & $7 / 0$ \\
\hline Freq. & 3 & 6 & 2 & 0 & 4 & 4 & 19 & $15 / 4$ \\
\hline$[\mathrm{mM}]$ & 0.172 & 15.43 & & & 1.035 & 0.039 & \multicolumn{2}{|c|}{ Selection $\geq 4$} \\
\hline & \multicolumn{6}{|c|}{ Total soluble solids $\mu 13.8\left(12.0-15.0^{\circ}\right.$ Brix $) \mathrm{R}^{2} 0.9034 \quad$ C.V. 5.51} & & \\
\hline 30.01 & ++++ & & & & & & 4 & $4 / 0$ \\
\hline 20.52 & & & ++ & -- & +++ & & 7 & $5 / 2$ \\
\hline-13.69 & & ++ & +++ & & & & 5 & $5 / 0$ \\
\hline Freq. & 4 & 2 & 5 & 2 & 3 & 0 & 16 & $14 / 2$ \\
\hline$[\mathrm{mM}]$ & & & & & & & \multicolumn{2}{|c|}{ Selection $\geq 3$} \\
\hline & \multicolumn{6}{|c|}{$\begin{array}{c}\text { Titratable acidity } \mu 0.3894(0.2546-0.4757 \% \text { malic acid }) R^{2} 0.9325 \quad \text { C.V. } \\
10.67\end{array}$} & & \\
\hline 62.51 & & & & & +++ & & 3 & $3 / 0$ \\
\hline 22.88 & +++ & ++ & -- & & & & 7 & $5 / 2$ \\
\hline-54.85 & & +++ & ++ & & & & 5 & $5 / 0$ \\
\hline Freq. & 3 & 5 & 4 & 0 & 3 & 0 & 15 & $13 / 2$ \\
\hline$[\mathrm{mM}]$ & & & & & & & \multicolumn{2}{|c|}{ Selection $\geq 3$} \\
\hline & \multicolumn{6}{|c|}{$\begin{array}{c}\text { Rel. Sugar Acidity } \mu 35.79\left(29.43-51.06^{\circ} \text { Brix / malic acid }\right) R^{2} \text { 0.9383 C.V. } \\
10.69\end{array}$} & & \\
\hline 69.95 & & +++ & & & & & 3 & $3 / 0$ \\
\hline-77.37 & & & & ++ & +++ & & 5 & $5 / 0$ \\
\hline Freq. & 0 & 3 & 0 & 2 & 3 & 0 & 8 & $8 / 0$ \\
\hline$[\mathrm{mM}]$ & & & & & & & \multicolumn{2}{|c|}{ Selection $\geq 2$} \\
\hline & \multicolumn{6}{|c|}{ Juice density $\mu 3.27\left(2.51-4.95 \mathrm{~g} \mathrm{ml}^{-1}\right) \mathrm{R}^{2} 0.9768$ C.V. 9.91} & & \\
\hline 68.16 & +++ & & ++ & -- & & & 7 & $5 / 2$ \\
\hline 45.56 & & & & ++ & +++ & & 5 & $5 / 0$ \\
\hline-52.72 & & ++ & ++ & ++ & & & 6 & $6 / 0$ \\
\hline Freq. & 3 & 2 & 4 & 6 & 3 & 0 & 18 & $16 / 2$ \\
\hline$[\mathrm{mM}]$ & & & & & & & \multicolumn{2}{|c|}{ Selection $\geq 4$} \\
\hline & \multicolumn{6}{|c|}{ Percentage of juice $\mu 81.85(38.89-91.30 \%) \mathrm{R}^{2} 0.5101$ C.V. 34.26} & & \\
\hline 14.83 & & -- & & ++ & ++ & & 6 & $4 / 2$ \\
\hline 6.55 & & ++ & & +++ & & & 5 & $5 / 0$ \\
\hline-19.54 & & & ++ & & +++ & & 5 & $5 / 0$ \\
\hline-38.90 & +++ & ++ & -- & & & & 7 & $5 / 2$ \\
\hline Freq. & 3 & 6 & 4 & 5 & 5 & 0 & 23 & $19 / 4$ \\
\hline$[\mathrm{mM}]$ & 1.125 & 15.75 & & 0.045 & 0.720 & & \multicolumn{2}{|c|}{ Selection $\geq 5$} \\
\hline
\end{tabular}


Oviedo-Mireles JC et al. (2021). Not Bot Horti Agrobo 49(3):12409

\begin{tabular}{|c|c|c|c|c|c|c|c|c|}
\hline & \multicolumn{6}{|c|}{$\begin{array}{c}\left.\text { Total phenols } \mu \text { 480.14 (363.38 - } 637.58 \mu \mathrm{g} \text { gal acid gr }{ }^{-1} \text { p.f }\right) R^{2} 0.8029 \text { C.V. } \\
6.62\end{array}$} & \multirow[b]{2}{*}{6} & \multirow[b]{2}{*}{$6 / 0$} \\
\hline 84.37 & +++ & & & & +++ & & & \\
\hline 53.10 & - & & & ++ & +++ & & 7 & $5 / 2$ \\
\hline-63.19 & & +++ & ++ & & & & 5 & $5 / 0$ \\
\hline Freq. & 5 & 3 & 2 & 2 & 6 & 0 & 18 & $16 / 2$ \\
\hline$[\mathrm{mM}]$ & & & & & & & \multicolumn{2}{|c|}{ Selection $\geq 4$} \\
\hline & \multicolumn{6}{|c|}{$\begin{array}{c}\text { Antioxidant capacity } \mu 3.051 \text { (1.826 - } 4.594 \mathrm{mg} \text { trolox g }{ }^{-1} \text { p.f.) } \mathrm{R}^{2} 0.9029 \text { C.V. } \\
7.07\end{array}$} & & \\
\hline 79.16 & & & & ++ & +++ & & 5 & $5 / 0$ \\
\hline 35.81 & +++ & & & - & & & 5 & $3 / 2$ \\
\hline-36.46 & & & & +++ & -- & & 5 & $3 / 2$ \\
\hline-64.82 & & +++ & & & & ++ & 5 & $5 / 0$ \\
\hline Freq. & $3 \mathrm{~L}, \mathrm{C} ; \mathrm{SA}^{\mathrm{W}}$ & 3 L,C; SA & 0 & 7 & $5 \mathrm{~L}, \mathrm{C}$ & 2 & 20 & $16 / 4$ \\
\hline$[\mathrm{mM}]$ & $1.320^{* * X}$ & $12.72^{* *}$ & & & $1.048^{* *}$ & & \multicolumn{2}{|c|}{ Selection $\geq 4$} \\
\hline & \multicolumn{6}{|c|}{ Summary } & \multicolumn{2}{|c|}{ Total Prop.+/- } \\
\hline Subtotal & 30 & 35 & 24 & 24 & 35 & 6 & \multicolumn{2}{|c|}{154} \\
\hline Selection & $0 / 9$ & $2 / 9$ & $0 / 9$ & $2 / 9$ & $3 / 9$ & $0 / 9$ & \multicolumn{2}{|c|}{ Variables 3 / 9} \\
\hline Prop. +/- & $26 / 4$ & $33 / 2$ & $17 / 7$ & $18 / 6$ & $31 / 4$ & $4 / 2$ & \multicolumn{2}{|c|}{$129^{\mathrm{Z}} / 25$} \\
\hline[] & 1.320 & 15.75 & & & 1.048 & & \multicolumn{2}{|c|}{ Selec. $\geq 26(19)$} \\
\hline
\end{tabular}

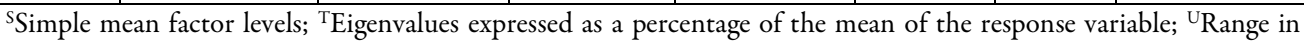
parentheses corresponds to the predicted values from the simple mean; ${ }^{\mathrm{V}}$ Each sign corresponds to multiples of 0.25

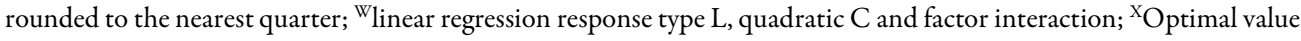
of the predicted factors and probability: significant ${ }^{*}(0.05 \leq \operatorname{Pr} \leq 0.01)$, highly significant ${ }^{* *}(\operatorname{Pr}<0.01)$, otherwise not significant; ${ }^{\mathrm{Y}}$ Total observed frequency for that variable, ${ }^{\mathrm{Z} T o t a l}$ frequency for the set of variables, factors with a subtotal equal to or greater than $20 \%$ are selected while variables greater than or equal to $15 \%$ are selected

Table 4. Selection factors, quality variables and bioactive compounds of apples, stored in a controlled atmosphere for 7 months and left on shelf for 1 day

\begin{tabular}{|c|c|c|c|c|c|c|c|c|}
\hline \multirow[b]{2}{*}{ Eigenvalues } & \multicolumn{8}{|c|}{ Factors / simple average [mM] } \\
\hline & $1.125^{S}$ & $\mathrm{Ca} \quad 15.75$ & $\begin{array}{c}\text { Co } \\
0.090\end{array}$ & $\begin{array}{c}\text { Mo } \\
0.045\end{array}$ & $\begin{array}{c}\text { SA } \\
0.720\end{array}$ & $\begin{array}{c}\mathrm{Mg} \\
0.045\end{array}$ & \multicolumn{2}{|c|}{$\begin{array}{l}\text { Eigenvectors } \\
\text { Total Prop.+/- }\end{array}$} \\
\hline & \multicolumn{6}{|c|}{ Colour $^{\mathrm{U}} \mu 60.00(56.88-62.92 \%) \mathrm{R}^{2} 0.7681$ C.V. 4.67} & & \\
\hline Freq. & $6^{\mathbb{W}}$ & 5 & 3 & 0 & 3 & 0 & $17^{\mathrm{Y}}$ & $12 / 5$ \\
\hline$[\mathrm{mM}]^{\mathrm{X}}$ & & & & & & & \multicolumn{2}{|c|}{ Selection $\geq 3$} \\
\hline & \multicolumn{6}{|c|}{ Firmness $\mu 10.65\left(9.38-12.05 \mathrm{lb} \mathrm{in}^{2}\right) \quad \mathrm{R}^{2} 0.9192 \quad$ C.V. 6.23} & & \\
\hline Freq. & 3 & 6 & 2 & 0 & 4 & 4 & 19 & $15 / 4$ \\
\hline$[\mathrm{mM}]$ & 0.172 & 15.43 & 0.103 & 0.035 & 1.035 & 0.039 & \multicolumn{2}{|c|}{ Selection $\geq 4$} \\
\hline & \multicolumn{6}{|c|}{ Total soluble solids $\mu 13.8\left(12.0-15.0^{\circ}\right.$ Brix $) \mathrm{R}^{2} 0.9034 \quad$ C.V. 5.51} & & \\
\hline Freq. & 4 & 2 & 5 & 2 & 3 & 0 & 16 & $14 / 2$ \\
\hline$[\mathrm{mM}]$ & & & & & & & \multicolumn{2}{|c|}{ Selection $\geq 3$} \\
\hline & \multicolumn{6}{|c|}{$\begin{array}{c}\text { Titratable acidity } \mu 0.3894(0.2546-0.4757 \% \text { malic acid }) R^{2} 0.9325 \quad \text { C.V. } \\
10.67\end{array}$} & & \\
\hline Freq. & 3 & 5 & 4 & 0 & 3 & 0 & 15 & $13 / 2$ \\
\hline$[\mathrm{mM}]$ & & & & & & & \multicolumn{2}{|c|}{ Selection $\geq 3$} \\
\hline & \multicolumn{6}{|c|}{$\begin{array}{c}\text { Rel. TSS/acidity } \mu 35.79\left(29.43-51.06^{\circ} \text { Brix/ malic acid }\right) R^{2} 0.9383 \text { C.V. } \\
10.69\end{array}$} & & \\
\hline Freq. & 0 & 3 & 0 & 2 & 3 & 0 & 8 & $8 / 0$ \\
\hline$[\mathrm{mM}]$ & & & & & & & \multicolumn{2}{|c|}{ Selection $\geq 2$} \\
\hline & \multicolumn{6}{|c|}{ Juice density $\mu 3.27\left(2.51-4.95 \mathrm{~g} \mathrm{ml}^{-1}\right) \mathrm{R}^{2} 0.9768$ C.V. 9.91} & & \\
\hline Freq. & 3 & 2 & 4 & 6 & 3 & 0 & 18 & $16 / 2$ \\
\hline$[\mathrm{mM}]$ & & & & & & & \multicolumn{2}{|c|}{ Selection $\geq 4$} \\
\hline
\end{tabular}


Oviedo-Mireles JC et al. (2021). Not Bot Horti Agrobo 49(3):12409

\begin{tabular}{|c|c|c|c|c|c|c|c|c|}
\hline & \multicolumn{6}{|c|}{ Percentage of juice $\mu 81.85(38.89-91.30 \%) \mathrm{R}^{2}$ 0.5101 C.V. 34.26} & \multirow[b]{2}{*}{23} & \multirow[b]{2}{*}{$19 / 4$} \\
\hline Freq. & 3 & 6 & 4 & 5 & 5 & 0 & & \\
\hline$[\mathrm{mM}]$ & 1.125 & 15.75 & 0.090 & 0.045 & 0.720 & 0.045 & \multicolumn{2}{|c|}{ Selection $\geq 5$} \\
\hline & \multicolumn{6}{|c|}{$\begin{array}{l}\text { Total phenols } \mu 480.14\left(363.38-637.58 \mu g_{\text {gal acid gr }}^{-1} \text { p.f) } R^{2} 0.8029 \text { C.V. }\right. \\
6.62\end{array}$} & & \\
\hline Freq. & 5 & 3 & 2 & 2 & 6 & 0 & 18 & $16 / 2$ \\
\hline$[\mathrm{mM}]$ & & & & & & & \multicolumn{2}{|c|}{ Selection $\geq 4$} \\
\hline & \multicolumn{6}{|c|}{$\begin{array}{c}\text { Antioxidant capacity } \mu 3.051 \text { (1.826-4.594 } \mathrm{mg} \text { trolox } \mathrm{g}^{-1} \text { p.f.) } \mathrm{R}^{2} 0.9029 \mathrm{C} . \mathrm{V} \text {. } \\
7.07\end{array}$} & & \\
\hline Freq. & $3 \mathrm{~L}, \mathrm{C} ; \mathrm{SA}^{\mathrm{W}}$ & $3 \mathrm{~L}, \mathrm{C} ; \mathrm{SA}$ & 0 & 7 & $5 \mathrm{~L}, \mathrm{C}$ & 2 & 20 & $16 / 4$ \\
\hline$[\mathrm{mM}]$ & $1.320^{* * X}$ & $12.72^{* *}$ & & & $1.048^{* *}$ & & \multicolumn{2}{|c|}{ Selection $\geq 4$} \\
\hline & \multicolumn{6}{|c|}{ Summary } & \multicolumn{2}{|c|}{ Total Prop.+/- } \\
\hline Subtotal & 30 & 35 & 24 & 24 & 35 & 6 & \multicolumn{2}{|c|}{154} \\
\hline Selection & $0 / 9$ & $2 / 9$ & $0 / 9$ & $2 / 9$ & $3 / 9$ & $0 / 9$ & \multicolumn{2}{|c|}{ Variables 3 / 9} \\
\hline Prop. +/- & $26 / 4$ & $33 / 2$ & $17 / 7$ & $18 / 6$ & $31 / 4$ & $4 / 2$ & \multicolumn{2}{|c|}{$129^{\mathrm{Z}} / 25$} \\
\hline [] & 1.320 & 15.75 & & & 1.048 & & \multicolumn{2}{|c|}{ Selec. $\geq 26(19)$} \\
\hline
\end{tabular}

${ }^{S}$ Simple mean factor levels; ${ }^{U}$ Range in brackets corresponds to the predicted values from the simple mean; ${ }^{\mathbb{W}}$ linear regression response type $\mathrm{L}$, quadratic $\mathrm{C}$ and factor interaction; ${ }^{\mathrm{x}} \mathrm{Optimal}$ value of the predicted factors and probability: significant ${ }^{*}(0.05 \leq \operatorname{Pr} \leq 0.01)$, highly significant ${ }^{* *}(\operatorname{Pr}<0.01)$, otherwise not significant; ${ }^{\mathrm{Y}}$ Total observed frequency for that variable, ${ }^{\mathrm{Z} T o t a l}$ frequency for the set of variables, those factors with a subtotal equal or greater than $20 \%$ are selected while variables greater or equal to $15 \%$ are selected

\section{Fruit quality}

The sum of the eigenvector weighting values in the statistical analysis of the four evaluated shelf-life dates, $\mathrm{K}, \mathrm{Ca}, \mathrm{SA}$ and $\mathrm{Co}$, were the selected factors in order of importance, as well as the highest observed application concentration values in $\mathrm{mM}$, are presented in Table 5 .

Table 5. Weighting of eigenvectors by day of shelf life, to select factors and application concentrations

\begin{tabular}{|l|c|c|c|c|}
\hline \multirow{2}{*}{ Factor } & \multicolumn{3}{|c|}{ Shelf days and Eingenvectors [mM] } \\
\cline { 2 - 5 } & 1 & 5 & 9 & 13 \\
\hline $\mathrm{K}$ & $30[1.320]$ & $41[1.483]$ & $38[1.125]$ & $36[1.285]$ \\
\hline $\mathrm{Ca}$ & $35[15.75]$ & $35[21.17]$ & $29[15.75]$ & $34[15.00]$ \\
\hline $\mathrm{SA}$ & $35[1.048]$ & $31[1.047]$ & $35[0.720]$ & $23[1.196]$ \\
\hline $\mathrm{Co}$ & & & $32[0.090]$ & \\
\hline
\end{tabular}

The weighting of eigenvectors for the selection of the quality variables, and to maintain them in the desired optimum, were in order of importance, with the maximum values of the original data range; firmness in $\mathrm{lb}^{\mathrm{in}} \mathrm{n}^{2}(12.05$ at day one, 11.56 at five days and 11.38 at thirteen days); juice percentage ( 91.30 at day one and 80.31 at thirteen days); titratable acidity with $0.4442 \%$ malic acid at day five. On the other hand, with the minimum values of the original data range were; juice density $1.81 \mathrm{~g} \mathrm{ml}^{-1}$ at day nine); and $12.40{ }^{\circ} \mathrm{Brix}$ TSS at day five, data shown in Table 6. 
Table 6. Weighting of eigenvectors by day of shelf-life for variable selection, mean and original range

\begin{tabular}{|c|c|c|c|c|c|c|c|c|}
\hline \multirow[t]{2}{*}{ Variable } & \multicolumn{4}{|c|}{$\begin{array}{l}\text { Weighting of } \\
\text { eigenvalues }\end{array}$} & \multicolumn{4}{|c|}{ Value of the mean and (original range) } \\
\hline & 1 & 5 & 9 & 13 & 1 & 5 & 9 & 13 \\
\hline Firmness & 19 & 20 & & 17 & $\begin{array}{c}10.65 \\
(9.38-12.05)\end{array}$ & $\begin{array}{c}10.49 \\
(9.84-11.56)\end{array}$ & & $\begin{array}{c}10.05 \\
(8.87-11.38)\end{array}$ \\
\hline \% Juice & 23 & & & 17 & $\begin{array}{c}81.85 \\
(38.89-91.30)\end{array}$ & & & \\
\hline & & & 26 & & & & & \\
\hline $\begin{array}{c}\text { Acidity } \\
\text { titratable }\end{array}$ & & 24 & & & & $\begin{array}{c}0.3583 \\
(0.2881-0.4442)\end{array}$ & & \\
\hline TSS & & 21 & & & & $\begin{array}{c}13.80 \\
(12.40-15.40)\end{array}$ & & \\
\hline $\begin{array}{c}\text { Total } \\
\text { phenols }\end{array}$ & & & & 20 & & & & $\begin{array}{c}434.097 \\
(292.42-600.48) \\
\end{array}$ \\
\hline $\begin{array}{c}\text { Antioxidant } \\
\text { capacity }\end{array}$ & 20 & & & & $\begin{array}{c}3.051 \\
(1.83-4.59)\end{array}$ & & & \\
\hline
\end{tabular}

Firmness $\left(\mathrm{lb} \mathrm{in}^{2}\right)$, juice percentage (\%), juice density $\left(\mathrm{g} \mathrm{ml}^{-1}\right)$, titratable acidity (\% malic acid), TSS ( $\left.{ }^{\circ} \mathrm{Brix}\right)$, total phenols ( $\mu$ g gal acid $\mathrm{g}^{-1}$ p.f.) and antioxidant capacity ( $\mathrm{mg}$ trolox $\mathrm{g}^{-1}$ p.f.).

Previous studies have shown that SA dives, at an adequate concentration, maintain postharvest quality during storage (Promyou and Supapvanich, 2016). For apple fruit to be accepted in some markets, firmness must be at least 62.3 N (Delong et al., 2000). Our results of postharvest immersion of apple fruit cv 'Golden Delicious' with the combination of K, Ca and SA at concentrations of $1.285 \mathrm{mM}, 15.00 \mathrm{mM}$ and $1.196 \mathrm{mM}$ respectively, 13 days after controlled atmosphere storage for 7 months, can maintain firmness at $11.38 \mathrm{lb}^{2}$, and are similar to those reported. Supapvanich et al. (2018), showed that immersion of wax apple fruits in SA at a concentration of $0.5 \mathrm{mM}$ maintained firmness, being higher with an immersion at $1.0 \mathrm{mM}$. These results confirms that SA stimulates phenylalanine ammonia lyase (PAL) activity (Dong et al., 2010), induces cell swelling and inhibits cell wall hydrolase activities, and cellulase, polygalacturonase (PG), lipoxygenase (LOX) and pectin methylesterase (PME) enzymes that degrade the membrane (Asghari and Aghdam, 2010). Similar results in rambutan (Manganaris et al., 2007) and in peach fruits, which, maintained the firmness (Supapvanich 2015). Thus, exogenous application of SA improves defence mechanisms and antioxidant production in fruits during storage, leading to a decrease in cell membrane lipid peroxidation (Wei et al., 2011).

Similar work to ours using different combinations of treatments in apple found a significant increase in firmness when combining $\mathrm{CaCl}_{2}(1 \%$ and $2 \%)$ and $\mathrm{MgCl}_{2}(1 \%$ and $2 \%)$ salts to maintain higher tissue firmness (Farag and Nagy, 2012). Shafiee et al. (2010), showed that strawberry dives treated postharvest with $2.0 \mathrm{mM}$ SA combined with $1.0 \% \mathrm{CaCl}_{2}$ after cold storage had increased firmness. In papaya, a concentration of $2.0 \mathrm{mM}$ is necessary to delay the loss of firmness (Promyou and Supapvanich, 2016). They report that, immersion of apple in $3.5 \% \mathrm{CaCl}_{2}$ solutions for a period of $30 \mathrm{~s}$, is sufficient to significantly reduce the Bitter pit, but with no effect on fruit firmness (Torres et al., 2017). However, Cepeda-Castañeda et al. (2014), found that, the highest flesh firmness with a mean of $79.2 \mathrm{~N}$ and a high TSS/acidity ratio of 41.7 was obtained with immersions in a $6 \% \mathrm{CaCl}_{2}$ solution for 15 min postharvest. In plum fruit treated in $\mathrm{CaCl}_{2} \mathrm{immersion}$ at a concentration of $1.0 \mathrm{mM}$, Valero et al. (2002) found that fruit firmness was higher than that of control fruit in storage. On the other hand, Manganaris et al. (2007), in peach using three Ca sources and two immersion concentrations (62.5 and $187.5 \mathrm{mM} \mathrm{Ca}$ ), report that treatment with Ca salts at $62.5 \mathrm{mM}$ was as effective as the higher concentration, maintaining tissue firmness during storage.

In our study, TSS can be maintained at $12.40{ }^{\circ} \mathrm{Brix}$, and TA with $0.4442 \%$ malic acid, which is very acceptable at 5 days after storage. If the fruit is harvested ripe, TSS slightly increases in concentration after 
harvest, starch (higher at harvest) is converted to sugars through hydrolysis over time (Musacchi and Serra. 2018), to aid respiration (Mesa et al., 2016). Previous work showed that SA concentration in immersion did not affect TSS and TA in wax apple (Supapvanich et al., 2018), in rambutan (Supapvanich 2015). Kazemi et al. (2011) showed that SA treatments delayed the decrease in titratable acidity during ripening of kiwifruit, similar results in pineapple (Lu et al., 2011). In postharvest (Guerra and Casquero, 2010) with apple fruit treated by immersion with $\mathrm{CaCl}_{2}$ at a concentration of $2 \%$, for $30 \mathrm{~s}$, after 60 days of cold storage, they report that the decrease in firmness was lower, but after 120 days of cold storage, there was no difference between treated and untreated fruit but, they were useful to retain the acidity of the fruit until 120 days of storage. Manganaris et al. (2007) report that the TSS and TA content of peach fruit was not influenced by postharvest Ca dives. Similar work to ours, Shafiee et al. (2010), applied $2.0 \mathrm{mM} \mathrm{SA}$ dives combined with $1.0 \% \mathrm{CaCl}_{2}$, after cold storage, , showed that postharvest treated strawberry fruit did not influence TSS and TA compared to the control. However, Bal (2016), in nectarine with exogenous application of SA, reports a gradual decrease in titratable acidity with prolonged storage.

\section{Bioactive compounds}

In our results, total phenols (TF) with the combination of $\mathrm{K}, \mathrm{Ca}$ and $\mathrm{SA}$ at concentrations of 1.285 $\mathrm{mM}, 15.00 \mathrm{mM}$ and $1.196 \mathrm{mM}$ respectively, can be maintained at $600.48 \mu \mathrm{g}$ acid gal g ${ }^{-1} \mathrm{FW}$ at 13 days of shelf life, and antioxidant capacity (AC) at $4.59 \mathrm{mg}$ trolox $\mathrm{g}^{-1} \mathrm{FW}$ at the first day of shelf life with concentrations of $1.320 \mathrm{mM} \mathrm{K}, 15.75 \mathrm{mM} \mathrm{Ca}$ and $1.048 \mathrm{mM}$ SA. Previous work showed that immersion of wax apple fruits in SA at a concentration of $0.5 \mathrm{mM}$ enhanced the bioactive compounds than using $1.0 \mathrm{mM}$, demonstrating that their content is dose dependent (Supapvanich et al., 2018). This confirms that SA stimulates phenylalanine ammonia lyase (PAL) activity and the antioxidant activities of the enzymes superoxide dismutase (SOD), catalase (CAT) and peroxidase (POD), leading to an increase in phenolic acids (Dong et al., 2010), in addition to bioactive compounds, which provides health benefits (Supapvanich and Promyou. 2013). In a similar work with SA immersion, Wei et al. (2011) found that SA induced the maximum postharvest phenolic concentration in immersion-treated asparagus at a concentration of $1.0 \mathrm{mM}$, as well as containing a higher concentration of DPPH scavenging activity. In sweet cherry treated with SA immersion, total anthocyanin and total phenols were improved during storage (Valero et al., 2011). In carnelian cherries treated in immersion with $2.0 \mathrm{mM} \mathrm{SA}$, Dokhanieh et al. (2013) reported that the content of total phenols and flavonoids increased significantly during postharvest storage, while cherries treated with a concentration of $1.0 \mathrm{mM}$ had higher DPPH radical scavenging capacity. In nectarine with exogenous application of SA Bal (2016) found a higher concentration of phenolic compounds and flavonoids with prolonged storage. SA at an adequate concentration maintains postharvest quality, (Promyou and Supapvanich, 2016) showed that, immersions at a concentration of $2.0 \mathrm{mM}$ in papaya improved antioxidant capacity and total phenols during storage.

\section{Conclusions}

This article reports for the first time, the positive effect of the combination of $\mathrm{K}, \mathrm{SA}$, and Ca postharvest immersion with the appropriate concentration: K $1.285 \mathrm{mM}$, Ca $15.00 \mathrm{mM}$, SA $1.196 \mathrm{mM}$, values to maintain the quality variables and bioactive compounds in the desired optimum, for apple fruits cv 'Golden Delicious', stored in a controlled atmosphere for 7 months. It was obtained that the factors with the greatest contribution with the highest weight, through the analysis of the 4 shelf-life dates, were $\mathrm{K}, \mathrm{Ca}$, and SA in order of importance to preserve the desired quality variables (firmness, juice percentage, juice density, titratable acidity and total soluble solids) and bioactive compounds (total phenols and antioxidant capacity).

\section{Authors' Contributions}


Conceptualization: JMSP; Methodology: JCOM, LCNM, RMYM; Validation: JMSP, JCOM; Formal analysis: JMSP, RPL; Investigation: JCOM, LCNM, RMYM; Data curation: JMSP, RPL; Funding acquisition: JMSP, ES, RPL; Project administration: JMSP; Writing: JCOM, ES; Review and editing: JCOM, JMSP, ES, LCNM; All authors read and approved the final manuscript.

\section{Acknowledgements}

Thanks to the Consejo Nacional de Ciencia y Tecnología (CONACYT) for the scholarship of Julio César Oviedo Mireles, scholarship number: 45651.

\section{Conflict of Interests}

The authors declare that there are no conflicts of interest related to this article.

\section{References}

Asghari M, Morteza SA (2010). Impact of salicylic acid on postharvest physiology of horticultural crops. Trends in Food Science and Technology 21(10):502-509. https://doi.org/10.1016/j.tifs.2010.07.009

Bal E (2016). Combined treatment of modified atmosphere packaging and salicylic acid improves postharvest quality of nectarine (Prunus persica L.) Fruit. Journal of Agricultural Science and Technology 18(5):1345-1354.

Bartoshuk LM, Klee HJ (2013). Better fruits and vegetables through sensory analysis. Current Biology 23(9):R374-378. https://doi.org/10.1016/j.cub.2013.03.038

Brand-Williams W, Cuvelier ME, Berset C (1995). Use of a free radical method to evaluate antioxidant activity. LWT Food Science and Technology 28(1):25-30. https://doi.org/10.1016/S0023-6438(95)80008-5

Brunetto G, Bastos De Melo GW, Moreno MQ, Tagliavini M (2016). The role of mineral nutrition on yields and fruit quality in grapevine, pear and apple. Revista Brasileira de Fruticultura 37(4):1089-1104. https://doi.org/10.1590/0100-2945-103/15

Casero T, Benavides A, Puy J, Recasens I (2004). Relationships between leaf and fruit nutrients and fruit quality attributes in Golden smoothee apples using multivariate regression techniques. Journal of Plant Nutrition 27(2):313-324. https://doi.org/10.1081/PLN-120027656

Cepeda-Castañeda I, Saucedo-Veloz C, Colinas-León MT, Rodríguez-Alcázar J (2014). Evaluación de tratamientos pre y postcosecha con $\mathrm{CaCl}_{2}$ en la frigoconservación y calidad de manzana cv. 'Golden Delicious'. Revista Iberoamericana de Tecnología Postcosecha 15(1):54-60.

Conway WS, Sams CE, Hickey KD (2002). Pre- and postharvest calcium treatment of apple fruit and its effect on quality. Acta Horticulturae 594:413-419. https://doi.org/10.17660/ActaHortic.2002.594.53

Delong JM, Prange RK, Harrison PA, McRae KB (2000). Comparison of a new apple firmness penetrometer with three standard instruments. Postharvest Biology and Technology 19(3):201-209. https://doi.org/10.1016/S09255214(00)00097-1

Dokhanieh AY, Aghdam MS, Fard JR, Hassanpour H (2013). Postharvest salicylic acid treatment enhances antioxidant potential of cornelian cherry fruit. Scientia Horticulturae 154:31-36. https://doi.org/10.1016/j.scienta.2013.01.025

Dong J, Wan G, Liang Z (2010). Accumulation of salicylic acid-induced phenolic compounds and raised activities of secondary metabolic and antioxidative enzymes in Salvia miltiorrhiza cell culture. Journal of Biotechnology 148(2-3):99-104. https://doi.org/10.1016/j.jbiotec.2010.05.009

Farag KM, Nagy NMN (2012). Effect of pre- and postharvest calcium and magnesium compounds and their combination treatments on 'Anna' apple fruit quality and shelf life. Journal of Horticultural Science \& Ornamental Plants $4(2): 155-168$ 
FAO (2020). Food and Agricultura Organization of the United Nations. Retrieved 2020 May from: http://fao.org/faostat/es/\#data/home

Guerra M, Casquero PA (2010). Summer pruning: An ecological alternative to postharvest calcium treatment to improve storability of high-quality apple cv. 'Reinette du Canada'. Food Science and Technology International 16(4):343-350. https://doi.org/10.1177/1082013210366977

Kazemi M, Aran M, Zamani S (2011). Effect of calcium chloride and salicylic acid treatments on quality characteristics of kiwifruit (Actinidia deliciosa cv. 'Hayward') during storage. American Journal of Plant Physiology 6(3):183189. https://doi.org/10.3923/ajpp.2011.183.189

Kyriacou MC, Rouphael Y (2017). Towards a new definition of quality for fresh fruits and vegetables. Scientia Horticulturae 234:463-469. https://doi.org/10.1016/j.scienta.2017.09.046

Lau OL, Yang SF (1976). Inhibition of etylene production by cobaltous ion. Plant Physiology 58(1):114-117. https://doi.org/10.1104/pp.581.114

Lu X, Sun D, Li Y, Shi W, Sun G (2011). Pre- and postharvest salicylic acid treatments alleviate internal browning and maintain quality of winter pineapple fruit. Scientia Horticulturae 130(2011):97-101. https://doi.org/10.1016/j.scienta.2011.06.017

Manganaris GA, Vasilakakis M, Diamantidis G, Mignani I (2007). Food chemistry the effect of postharvest calcium application on tissue calcium concentration, quality attributes, incidence of flesh browning and cell wall physicochemical aspects of peach fruits. Food Chemistry 100:1385-1392. https://doi.org/10.1016/j.foodchem.2005.11.036

Mesa K, Serra S, Masia A, Gagliardi F, Bucci D, Musacchi S (2016). Seasonal trends of starch and soluble carbohydrates in fruits and leaves of 'Abbé Fétel' pear trees and their relationship to fruit quality parameters. Scientia Horticulturae 211(2016):60-69. https://doi.org/10.1016/j.scienta.2016.08.008

Musacchi S, Serra S (2018). Apple fruit quality: overview on pre-harvest factors. Scientia Horticulturae 234(2018):409430. https://doi.org/10.1016/j.scienta.2017.12.057

Nautiyal N, Chatterjee Ch, (2004). Molybdenum stress-induced changes in growth and yield of Chickpea. Journal of Plant Nutrition 27(1):173-181. https://doi.org/10.1081/PLN-120027554

Promyou S, Supapvanich S (2016). Effects of salicylic acid immersion on physicochemical quality of Thai papaya fruit 'Kaek dam' during storage. Acta Horticulturae 1111:105-112. https://doi.org/10.17660/ActaHortic.2016.1111.16

El-Ramady HR, Domokos-Szabolcsy E, Abdalla NA, Taha HS, Fari M (2015). Postharvest management of fruits and vegetables storage. Sustainable Agriculture Reviews 15:77-78. https://doi.org/10.1007/978-3-319-09132-7_2

Salas-Salazar NA, Molina-Corral FJ, Berlanga-Reyes DL, Romo-Chacón A, Olivas G (2011). Influence of harvest date on the synthesis of volatile compounds in stored fruits of apples 'Golden Delicious' and 'Red Delicious'. Revista Fitotecnia Mexicana 34(4):257-267.

SAS (1989). SAS Institute Inc., SAS / STAT Software: Usage and Reference, Version 6, First Edition, Cary, NC: SAS Institute Inc.

Serra S, Leisso R, Giordani L, Kalcsits L, Musacchi S (2016). Crop load influences fruit quality, nutritional balance, and return bloom in 'Honeycrisp' apple. HortScience 51(3):236-44. https://doi.org/10.21273/HORTSCI.51.3.236

Shafiee, M, Taghavi TS, Babalar M (2010). Addition of salicylic acid to nutrient solution combined with postharvest treatments (hot water, salicylic acid, and calcium dipping) improved postharvest fruit quality of strawberry. Scientia Horticulturae 124(2010):40-45. https://doi.org/10.1016/j.scienta.2009.12.004

Singleton VL, Rossi JA (1965). Colorimetry of total phenolics with phosphomolybdic-phosphotungstic acid reagents. American Journal Enology and Viticulturae 16:144-158.

Supapvanich S, (2015). Effects of salicylic acid incorporated with lukewarm water dips on the quality and bioactive compounds of rambutan fruit (Nephelium lappaceum L.). CMU Journal of Natural Sciences 14(1):23-38. https://doi.org/10.12982/cmujns.2015.0069

Supapvanich S, Mitsang P, Youryon P, Techavuthiporn CH (2018). Postharvest quality maintenance and bioactive compounds enhancement in 'Taaptimjaan' wax apple during short - term storage by salicylic acid immersion. Horticulture, Environment, and Biotechnology 59(3):373-381. https://doi.org/10.1007/s13580-018-0044-9

Supapvanich S, Promyou S (2013). Efficiency of salicylic acid application on postharvest perishable crops. Editorial Springer Science+Business Media Dordrecht pp 339-354. https://doi.org/10.1007/978-94-007-6428-6 
Torres E, Recasens I, Lordan J, Alegre S (2017). Combination of strategies to supply calcium and reduce bitter pit in 'Golden Delicious' apples. Scientia Horticulturae 217(2017):179-188. https://doi.org/10.1016/j.scienta.2017.01.028

Soto PJ, Sánchez E, Uvalle M, Yáñez BJX, Montes MRN, Ruíz DF, Romero L (2001). Pre-harvest application dosages of aminoethoxyvinylglycine in relation to ripening, fruit drop and watercore in 'Red Delicious' and 'Golden Delicious' apples. International Journal of Experimental Botany 171-178.

Valero D, Pérez-Vicente A, Martínez-Romero D, Castillo S, Guillén F, Serrano M (2002). Plum storability improved after calcium and heat postharvest treatments: role of polyamines. Journal of Food Science 67(7):2571-2575. https://doi.org/10.1111/j.1365-2621.2002.tb08778.x

Valero D, Huertas M, Díaz-Mula P, Zapata J, Castillo S, Guillén F, Martínez-Romero D, Serrano M (2011). Postharvest treatments with salicylic acid, acetylsalicylic acid or oxalic acid delayed ripening and enhanced bioactive compounds and antioxidant capacity in sweet cherry. Journal of Agricultural and Food Chemistry 59(10):54835489. https://doi.org/10.1021/jf200873j

Vanoli M, Buccheri M (2012). Overview of the methods for assessing harvest maturity. Stewart Postharvest Reviews 8:111. https://doi.org/10.2212/spr.2012.1.4

Wei Y, Liu Z, Su Y, Liu D, Ye X (2011). Effect of salicylic acid treatment on postharvest quality, antioxidant activities, and free polyamines of asparagus. Journal of Food Science 76(2):126-132. https://doi.org/10.1111/j.17503841.2010.01987.x

Yfran M, Chabbal M, Píccoli A, Giménez L, Rodríguez V, Martínez G (2017). Fertilización foliar con potasio, calcio y boro. Incidencia sobre la nutrición y calidad de frutos en mandarino Nova. INCA Instituto Nacional de Ciencias Agrícolas Cultivos Tropicales 38(4):22-29.
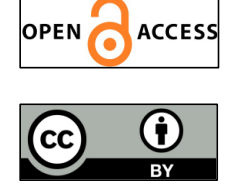

The journal offers free, immediate, and unrestricted access to peer-reviewed research and scholarly work. Users are allowed to read, download, copy, distribute, print, search, or link to the full texts of the articles, or use them for any other lawful purpose, without asking prior permission from the publisher or the author.

License - Articles published in Notulae Botanicae Horti Agrobotanici Cluj-Napoca are Open-Access, distributed under the terms and conditions of the Creative Commons Attribution (CC BY 4.0) License.

(c) Articles by the authors; UASVM, Cluj-Napoca, Romania. The journal allows the author(s) to hold the copyright/to retain publishing rights without restriction. 


\section{Salicylic acid and nutrient immersion to maintain apple quality and bioactive compounds in postharvest}

Supplementary files

Table S1. Factors, fruit quality and bioactive compounds of apple, stored in a controlled atmosphere for 7 months and left on the shelf for 5 days

\begin{tabular}{|c|c|c|c|c|c|c|c|c|}
\hline \multirow{3}{*}{ Eigenvalues } & \multicolumn{8}{|c|}{ Factors / simple average $[\mathrm{mM}]$} \\
\hline & K $1.125^{s}$ & Ca 15.75 & Co 0.090 & Mo 0.045 & SA 0.720 & $\operatorname{Mg} 0.045$ & \multicolumn{2}{|c|}{$\begin{array}{l}\text { Eigenvectors } \\
\text { Tot. Prop. +/ }\end{array}$} \\
\hline & \multicolumn{6}{|c|}{ Colour $^{\mathrm{U}} \mu 60.72(57.50-65.52 \%) \mathrm{R}^{2} 0.9657$ C.V. 1.86} & & \\
\hline $21.64^{\mathrm{T}}$ & & $+++^{\mathrm{V}}$ & & & & ++ & 5 & $5 / 0$ \\
\hline-10.77 & +++ & & & -- & & & 5 & $3 / 2$ \\
\hline-24.70 & & & ++ & & +++ & & 5 & $5 / 0$ \\
\hline Frec. & $3^{\mathrm{W}}$ & 3 & 2 & 2 & 3 & 2 & $15^{\mathrm{Y}}$ & $13 / 2$ \\
\hline$[\mathrm{mM}]$ & & & & & & & \multicolumn{2}{|c|}{ Selection $\geq 3$} \\
\hline & \multicolumn{6}{|c|}{ Firmness $\mu 10.49\left(9.84-11.56 \mathrm{lb}^{\mathrm{b}}{ }^{2}\right) \mathrm{R}^{2} 0.9885$ C.V. 1.40} & & \\
\hline 17.43 & +++ & & & & -- & & 5 & $3 / 2$ \\
\hline 11.95 & & & +++ & ++ & & & 5 & $5 / 0$ \\
\hline-6.11 & ++ & & & & +++ & & 5 & $5 / 0$ \\
\hline-10.87 & & & ++ & --- & & & 5 & $2 / 3$ \\
\hline Frec. & $5 \mathrm{C} ; \mathrm{SA}^{\mathrm{W}}$ & 0 & $5 \mathrm{C}$ & $5 \mathrm{C}$ & $5 \mathrm{C}$ & 0 & 20 & $15 / 5$ \\
\hline$[\mathrm{mM}]$ & $1.483^{\mathrm{X}}$ & & 0.083 & 0.062 & 0.121 & & \multicolumn{2}{|c|}{ Selection $\geq 4$} \\
\hline & \multicolumn{6}{|c|}{ Total soluble solids $\mu 13.80\left(12.40-15.40^{\circ}\right.$ Brix $) \mathrm{R}^{2} 0.9709$ C.V. 3.06} & & \\
\hline 32.98 & --- & & & & ++ & & 5 & $2 / 3$ \\
\hline 25.62 & +++ & & & & ++ & & 5 & $5 / 0$ \\
\hline 18.11 & & ++ & & & ++ & - & 6 & $4 / 2$ \\
\hline-27.33 & & +++ & & & & ++ & 5 & $5 / 0$ \\
\hline Frec. & $6 \mathrm{C}$ & $5 \mathrm{C}$ & 0 & 0 & $6 \mathrm{C}$ & $4 \mathrm{C}$ & 21 & $16 / 5$ \\
\hline$[\mathrm{mM}]$ & 0.852 & 12.61 & & & 1.047 & 0.042 & \multicolumn{2}{|c|}{ Selection $\geq 4$} \\
\hline & \multicolumn{6}{|c|}{ Titratable acidity $\mu 0.3583\left(0.2881-0.4442 \%\right.$ malic acid) $R^{2} 0.9527$ C.V. 7.91} & & \\
\hline 34.00 & --- & ++ & & & & & 5 & $2 / 3$ \\
\hline 18.86 & ++ & +++ & -- & & & & 7 & $5 / 2$ \\
\hline-10.40 & & & ++ & --- & & & 5 & $2 / 3$ \\
\hline-25.05 & ++ & & & ++ & +++ & & 7 & $7 / 0$ \\
\hline Frec. & 7 & 5 & & 5 & 3 & 0 & 24 & $16 / 8$ \\
\hline$[\mathrm{mM}]$ & 0.105 & 21.17 & & 0.042 & & & \multicolumn{2}{|c|}{ Selection $\geq 5$} \\
\hline & \multicolumn{6}{|c|}{ Rel. Sugar Acidity $\mu 38.80$ (32.56 - $45.12^{\circ}$ Brix / malic acid) R² 0.9413 C.V. 7.35} & & \\
\hline 48.49 & ++ & & & & +++ & & 5 & $5 / 0$ \\
\hline 17.89 & ++ & & & --- & & & 5 & $2 / 3$ \\
\hline-39.00 & & +++ & & & & & 3 & $3 / 0$ \\
\hline Frec. & 4 & 3 & 0 & 3 & 3 & 0 & 13 & $10 / 3$ \\
\hline$[\mathrm{mM}]$ & & & & & & & \multicolumn{2}{|c|}{ Selection $\geq 3$} \\
\hline & \multicolumn{6}{|c|}{ Juice density $\mu 2.60\left(1.84-3.57 \mathrm{~g} \mathrm{ml}^{-1}\right) \mathrm{R}^{2} 0.9582$ C.V. 11.40} & & \\
\hline 64.28 & +++ & ++ & & & & & 5 & $5 / 0$ \\
\hline 26.38 & & & & -- & +++ & & 5 & $3 / 2$ \\
\hline-22.50 & & +++ & ++ & & & & 5 & $5 / 0$ \\
\hline Frec. & 3 & 5 & 2 & 2 & 3 & 0 & 15 & $13 / 2$ \\
\hline
\end{tabular}


Oviedo-Mireles JC et al. (2021). Not Bot Horti Agrobo 49(3):12409

\begin{tabular}{|c|c|c|c|c|c|c|c|c|}
\hline$[\mathrm{mM}]$ & & & & & & & \multicolumn{2}{|c|}{ Selection $\geq 3$} \\
\hline & \multicolumn{6}{|c|}{ Percentage of juice $\mu 83.14(74.23-91.07 \%) \mathrm{R}^{2} 0.9705$ C.V. 3.55} & & \\
\hline 34.79 & $-\ldots$ & ++ & & & & & 5 & $2 / 3$ \\
\hline-8.99 & & & +++ & ++ & & & 5 & $5 / 0$ \\
\hline-14.44 & ++ & ++ & & & & ++ & 6 & $6 / 0$ \\
\hline Frec. & 5 & 4 & 3 & 2 & 0 & 2 & 16 & $13 / 3$ \\
\hline$[\mathrm{mM}]$ & & & & & & & \multicolumn{2}{|c|}{ Selection $\geq 3$} \\
\hline & \multicolumn{6}{|c|}{$\begin{array}{c}\left.\text { Total phenols } \mu \text { 475.710 (361.774 - } 713.387 \mu \mathrm{g} \text { gal acid gr }{ }^{-1} \text { p.f }\right) \mathrm{R}^{2} 0.7993 \text { C.V. } \\
7.34\end{array}$} & & \\
\hline 30.85 & & & & +++ & ++ & & 5 & $5 / 0$ \\
\hline-39.24 & & +++ & & & +++ & & 6 & $6 / 0$ \\
\hline-58.48 & +++ & ++ & & ++ & & & 7 & $7 / 0$ \\
\hline Frec. & 3 & 5 & 0 & 5 & 5 & 0 & 18 & $18 / 0$ \\
\hline$[\mathrm{mM}]$ & & & & & & & \multicolumn{2}{|c|}{ Selection $\geq 4$} \\
\hline & \multicolumn{6}{|c|}{$\begin{array}{c}\text { Antioxidant capacity } \mu 3.351 \text { (0.996- } 4.070 \mathrm{mg} \text { trolox } \mathrm{g}^{-1} \text { p.f.) } \mathrm{R}^{2} 0.9232 \mathrm{CV} \text {. } \\
6.16\end{array}$} & & \\
\hline 144.24 & ++ & & & & +++ & & 5 & $5 / 0$ \\
\hline 48.80 & +++ & ++ & -- & & & & 7 & $5 / 2$ \\
\hline-113.98 & & +++ & & & & & 3 & $3 / 0$ \\
\hline Frec. & 5 & 5 & 2 & 0 & 3 & 0 & 15 & $13 / 2$ \\
\hline$[\mathrm{mM}]$ & & & & & & & \multicolumn{2}{|c|}{ Selection $\geq 3$} \\
\hline & \multicolumn{6}{|c|}{ Summary } & \multicolumn{2}{|c|}{ Total prop. +/- } \\
\hline Subtotal & 41 & 35 & 18 & 24 & 31 & 8 & \multicolumn{2}{|c|}{157} \\
\hline Selection & $3 / 9$ & $1 / 9$ & $1 / 9$ & $1 / 9$ & $2 / 9$ & $1 / 9$ & \multicolumn{2}{|c|}{ Variables 3 / 9} \\
\hline Prop. +/- & $32 / 9$ & $35 / 0$ & $14 / 4$ & $11 / 13$ & $29 / 2$ & $6 / 2$ & \multicolumn{2}{|c|}{$127^{\mathrm{Z}} / 30$} \\
\hline$[\mathrm{mM}]$ & 1.483 & 21.17 & & & 1.047 & & \multicolumn{2}{|c|}{ Selec. $\geq 25(19)$} \\
\hline
\end{tabular}

${ }^{\mathrm{S} S i m p l e}$ mean factor levels; ${ }^{\mathrm{T}}$ Eigenvalues expressed as a percentage of the mean of the response variable; ${ }^{U}$ Range in parentheses corresponds to the predicted values from the simple mean; ${ }^{\mathrm{V}}$ Each sign corresponds to multiples of 0.25 rounded to the nearest quarter; ${ }^{\mathrm{W}}$ linear regression response type $\mathrm{L}$, quadratic $\mathrm{C}$ and factor interaction; ${ }^{\mathrm{X}} \mathrm{Optimal}$ value of the predicted factors and probability: significant ${ }^{*}(0.05 \leq \operatorname{Pr} \leq 0.01)$, highly significant ${ }^{* *}(\operatorname{Pr}<0.01)$, otherwise not significant; ${ }^{\mathrm{Y}}$ Total observed frequency for that variable, ${ }^{\mathrm{Z}}$ Total frequency for the set of variables, factors with a subtotal equal to or greater than $20 \%$ are selected while variables greater than or equal to $15 \%$ are selected 
Table S2. Selection of factors, quality variables and bioactive compounds of apples, stored in a controlled atmosphere for 7 months and left on the shelf for 5 days

\begin{tabular}{|c|c|c|c|c|c|c|c|c|}
\hline \multirow[b]{2}{*}{ Eigenvalues } & \multicolumn{8}{|c|}{ Factors / simple average $[\mathrm{mM}]$} \\
\hline & $\mathrm{K} 1.125^{\mathrm{S}}$ & Ca 15.75 & Co 0.090 & Mo 0.045 & SA 0.720 & $\operatorname{Mg} 0.045$ & \multicolumn{2}{|c|}{$\begin{array}{l}\text { Eigenvectors } \\
\text { Tot. Prop. }+/-\end{array}$} \\
\hline & \multicolumn{6}{|c|}{ Colour $^{\mathrm{U}} \mu 60.72(57.50-65.52 \%) \mathrm{R}^{2} 0.9657$ C.V. 1.86} & & \\
\hline Frec. & $3^{\mathrm{W}}$ & 3 & 2 & 2 & 3 & 2 & $15^{\mathrm{Y}}$ & $13 / 2$ \\
\hline$[\mathrm{mM}]$ & & & & & & & \multicolumn{2}{|c|}{ Selection $\geq 3$} \\
\hline & \multicolumn{6}{|c|}{ Firmness $\mu 10.49\left(9.84-11.56 \mathrm{lb}^{1}\right.$ in $\left.^{2}\right) \mathrm{R}^{2} 0.9885$ C.V. 1.40} & & \\
\hline Frec. & $5 \mathrm{C} ; \mathrm{SA}$ & 0 & $5 \mathrm{C}$ & $5 \mathrm{C}$ & $5 \mathrm{C}$ & 0 & 20 & $15 / 5$ \\
\hline$[\mathrm{mM}]$ & $1.483^{\mathrm{X}}$ & & 0.083 & 0.062 & 0.121 & & \multicolumn{2}{|c|}{ Selection $\geq 4$} \\
\hline & \multicolumn{6}{|c|}{ Total soluble solids $\mu 13.80\left(12.40-15.40^{\circ}\right.$ Brix $) R^{2} 0.9709$ C.V. 3.06} & & \\
\hline Frec. & 6C & $5 \mathrm{C}$ & 0 & 0 & $6 \mathrm{C}$ & $4 \mathrm{C}$ & 21 & $16 / 5$ \\
\hline$[\mathrm{mM}]$ & 0.852 & 12.61 & & & 1.047 & 0.042 & \multicolumn{2}{|c|}{ Selection $\geq 4$} \\
\hline & \multicolumn{6}{|c|}{ Titratable acidity $\mu 0.3583(0.2881-0.4442 \%$ malic acid $) R^{2} 0.9527$ C.V. 7.91} & & \\
\hline Frec. & 7 & 5 & 4 & 5 & 3 & 0 & 24 & $16 / 8$ \\
\hline$[\mathrm{mM}]$ & 0.105 & 21.17 & 0.099 & 0.042 & 0.736 & 0.035 & \multicolumn{2}{|c|}{ Selection $\geq 5$} \\
\hline & \multicolumn{6}{|c|}{$\begin{array}{c}\text { Rel. Sugar Acidity } \mu 38.80\left(32.56-45.12^{\circ} \mathrm{Brix} / \mathrm{malic} \text { acid }\right) \mathrm{R}^{2} \text { 0.9413 C.V. } \\
7.35\end{array}$} & & \\
\hline Frec. & 4 & 3 & 0 & 3 & 3 & 0 & 13 & $10 / 3$ \\
\hline$[\mathrm{mM}]$ & & & & & & & \multicolumn{2}{|c|}{ Selection $\geq 3$} \\
\hline & \multicolumn{6}{|c|}{ Juice density $\mu 2.60\left(1.84-3.57 \mathrm{~g} \mathrm{ml}^{-1}\right) \mathrm{R}^{2}$ 0.9582 C.V. 11.40} & & \\
\hline Frec. & 3 & 5 & 2 & 2 & 3 & 0 & 15 & $13 / 2$ \\
\hline$[\mathrm{mM}]$ & & & & & & & \multicolumn{2}{|c|}{ Selection $\geq 3$} \\
\hline & \multicolumn{6}{|c|}{ Percentage of juice $\mu 83.14(74.23-91.07 \%) \mathrm{R}^{2} 0.9705$ C.V. 3.55} & & \\
\hline Frec. & 5 & 4 & 3 & 2 & 0 & 2 & 16 & $13 / 3$ \\
\hline$[\mathrm{mM}]$ & & & & & & & \multicolumn{2}{|c|}{ Selection $\geq 3$} \\
\hline & \multicolumn{6}{|c|}{$\begin{array}{c}\text { Total phenols } \mu 475.710 \text { (361.774 - } 713.387 \mu \mathrm{g} \text { gal acid gr }{ }^{-1} \text { p.f) } \mathrm{R}^{2} 0.7993 \text { C.V. } \\
7.34\end{array}$} & & \\
\hline Frec. & 3 & 5 & 0 & 5 & 5 & 0 & 18 & $18 / 0$ \\
\hline$[\mathrm{mM}]$ & & & & & & & \multicolumn{2}{|c|}{ Selection $\geq 4$} \\
\hline & \multicolumn{6}{|c|}{$\begin{array}{c}\text { Antioxidant capacity } \mu 3.351\left(0.996-4.070 \mathrm{mg} \text { trolox g }{ }^{-1} \text { p.f. }\right) \mathrm{R}^{2} 0.9232 \mathrm{CV} . \\
6.16\end{array}$} & & \\
\hline Frec. & 5 & 5 & 2 & 0 & 3 & 0 & 15 & $13 / 2$ \\
\hline$[\mathrm{mM}]$ & & & & & & & \multicolumn{2}{|c|}{ Selection $\geq 3$} \\
\hline & \multicolumn{6}{|c|}{ Summary } & \multicolumn{2}{|c|}{ Total prop. $+/-$} \\
\hline Subtotal & 41 & 35 & 18 & 24 & 31 & 8 & & 57 \\
\hline Selection & $3 / 9$ & $1 / 9$ & $1 / 9$ & $1 / 9$ & $2 / 9$ & $1 / 9$ & \multicolumn{2}{|c|}{ Variables $3 / 9$} \\
\hline Prop. +/- & $32 / 9$ & $35 / 0$ & $14 / 4$ & $11 / 13$ & $29 / 2$ & $6 / 2$ & \multicolumn{2}{|c|}{$127^{\mathrm{Z}} / 30$} \\
\hline$[\mathrm{mM}]$ & 1.483 & 21.17 & & & 1.047 & & \multicolumn{2}{|c|}{ Selec. $\geq 25(19)$} \\
\hline
\end{tabular}

${ }^{S}$ Simple mean factor levels; ${ }^{U}$ Range in brackets corresponds to the predicted values from the simple mean; ${ }^{\mathbb{W}}$ linear regression response type $\mathrm{L}$, quadratic $\mathrm{C}$ and factor interaction; ${ }^{\mathrm{x}} \mathrm{Optimal}$ value of the predicted factors and probability: significant ${ }^{*}(0.05 \leq \operatorname{Pr} \leq 0.01)$, highly significant ${ }^{* *}(\operatorname{Pr}<0.01)$, otherwise not significant; ${ }^{\mathrm{T}}$ Total observed frequency for that variable, ${ }^{\mathrm{Z}}$ Total frequency for the set of variables, those factors with a subtotal equal or greater than $20 \%$ are selected while variables greater or equal to $15 \%$ are selected 
Table S3. Factors, fruit quality and bioactive compounds of apple, stored in a controlled atmosphere for 7 months and left on the shelf for 9 days

\begin{tabular}{|c|c|c|c|c|c|c|c|c|}
\hline \multirow[b]{2}{*}{ Eigenvalues } & \multicolumn{6}{|c|}{ Factors / simple average $[\mathrm{mM}]$} & \multirow{2}{*}{\multicolumn{2}{|c|}{$\begin{array}{l}\text { Eigenvectors } \\
\text { Tot. Prop. }+/ \text { - }\end{array}$}} \\
\hline & $\mathrm{K} 1.125^{\mathrm{S}}$ & Ca 15.75 & Co 0.090 & Mo 0.045 & SA 0.720 & $\operatorname{Mg} 0.045$ & & \\
\hline & \multicolumn{6}{|c|}{ Colour $^{\mathrm{U}} \mu \mathrm{C3.76}(59.58-66.46 \%) \mathrm{R}^{2} 0.8019$ C.V. 4.15} & & \\
\hline $6.09^{\mathrm{T}}$ & $-\mathrm{N}^{\mathrm{V}}$ & & ++ & & +++ & & 7 & $5 / 2$ \\
\hline 2.77 & ++ & -- & & & ++ & ++ & 8 & $6 / 2$ \\
\hline-6.74 & ++ & +++ & & & & & 5 & $5 / 0$ \\
\hline Frec. & $6^{\mathbb{W}}$ & 5 & 2 & 0 & 5 & 2 & $20^{Y}$ & $16 / 4$ \\
\hline$[\mathrm{mM}]$ & & & & & & & \multicolumn{2}{|c|}{ Selection $\geq 4$} \\
\hline & \multicolumn{6}{|c|}{ Firmness $\mu 10.30\left(9.17-11.51 \mathrm{lb}^{1} \mathrm{in}^{2}\right) \mathrm{R}^{2} 0.9685$ C.V. 3.95} & & \\
\hline 78.98 & & & ++ & & +++ & & 5 & $5 / 0$ \\
\hline-39.52 & +++ & ++ & & & & & 5 & $5 / 0$ \\
\hline-66.03 & & +++ & & & & & 3 & $3 / 0$ \\
\hline Frec. & 3 & 5 & 2 & 0 & 3 & 0 & 13 & $13 / 0$ \\
\hline$[\mathrm{mM}]$ & & & & & & & \multicolumn{2}{|c|}{ Selection $\geq 3$} \\
\hline & \multicolumn{6}{|c|}{ Total soluble solids $\mu 13.7$ (12.0 - 14.6 ${ }^{\circ}$ Brix) $\mathrm{R}^{2}$ 0.9629 C.V. 3.30} & & \\
\hline 27.07 & ++++ & & & & & & 4 & $4 / 0$ \\
\hline 25.54 & & & & & ++++ & & 4 & $4 / 0$ \\
\hline-20.12 & & ++ & +++ & & & & 5 & $5 / 0$ \\
\hline Frec. & 4 & 2 & 3 & 0 & 4 & 0 & 13 & $13 / 0$ \\
\hline$[\mathrm{mM}]$ & & & & & & & \multicolumn{2}{|c|}{ Selection $\geq 3$} \\
\hline & \multicolumn{6}{|c|}{ Titratable acidity $\mu 0.3532\left(0.3015-0.3953 \%\right.$ malic acid) $R^{2} 0.9710$ C.V. 4.95} & & \\
\hline 56.07 & & & ++ & & +++ & & 5 & $5 / 0$ \\
\hline 42.31 & ++++ & & & & & & 4 & $4 / 0$ \\
\hline-56.18 & & +++ & ++ & & & ++ & 7 & $7 / 0$ \\
\hline Frec. & 4 & 3 & 4 & 0 & 3 & 2 & 16 & $16 / 0$ \\
\hline$[\mathrm{mM}]$ & & & & & & & \multicolumn{2}{|c|}{ Selection $\geq 3$} \\
\hline & \multicolumn{6}{|c|}{$\begin{array}{c}\text { Rel. Sugar Acidity } \mu 38.88 \text { (33.45 - } \frac{1}{46.36}{ }^{\circ} \text { Brix / malic acid) } R^{2} 0.9436 \text { C.V. } \\
7.15\end{array}$} & & \\
\hline 39.94 & & +++ & & & & ++ & 5 & $5 / 0$ \\
\hline-21.54 & +++ & ++ & & & & -- & 7 & $5 / 2$ \\
\hline-40.36 & & & ++ & ++ & +++ & & 7 & $7 / 0$ \\
\hline Frec. & 3 & 5 & 2 & 2 & 3 & 4 & 19 & $17 / 2$ \\
\hline$[\mathrm{mM}]$ & & & & & & & \multicolumn{2}{|c|}{ Selection $\geq 4$} \\
\hline & \multicolumn{6}{|c|}{ Juice density $\mu 2.15\left(1.81-2.64 \mathrm{~g} \mathrm{ml}^{-1}\right) \mathrm{R}^{2} 0.8788$ C.V. 12.20} & & \\
\hline 34.6 & +++ & & & ++ & -- & & 7 & $5 / 2$ \\
\hline 12.9 & -- & & ++ & ++ & & & 6 & $4 / 2$ \\
\hline-8.4 & & & & +++ & +++ & & 6 & $6 / 0$ \\
\hline-14.4 & ++ & & +++ & & ++ & & 7 & $7 / 0$ \\
\hline Frec. & 7 & 0 & 5 & 7 & 7 & 0 & 26 & $22 / 4$ \\
\hline$[\mathrm{mM}]$ & $1.125^{\mathrm{X}}$ & 15.75 & 0.090 & 0.045 & 0.720 & 0.045 & \multicolumn{2}{|c|}{ Selection $\geq 5$} \\
\hline & \multicolumn{6}{|c|}{ Percentage of juice $\mu 87.64$ (78.08 - 95.10\%) R R 0.9149 C.V. 4.44} & & \\
\hline 18.73 & -- & +++ & & & & & 5 & $3 / 2$ \\
\hline-5.82 & & & +++ & & -- & & 5 & $3 / 2$ \\
\hline-13.63 & ++ & & ++ & & +++ & & 7 & $7 / 0$ \\
\hline Frec. & 4 & 3 & 5 & 0 & 5 & 0 & 17 & $13 / 4$ \\
\hline$[\mathrm{mM}]$ & & & & & & & \multicolumn{2}{|c|}{ Selection $\geq 3$} \\
\hline
\end{tabular}


Oviedo-Mireles JC et al. (2021). Not Bot Horti Agrobo 49(3):12409

\begin{tabular}{|c|c|c|c|c|c|c|c|c|}
\hline \multirow[b]{2}{*}{32.83} & \multicolumn{6}{|c|}{$\begin{array}{c}\text { Total phenols } \mu 469.968 \text { (356.939 - 590.806 } \mu \mathrm{g} \text { gal acid gr }{ }^{-1} \text { p.f) } \mathrm{R}^{2} 0.7977 \text { C.V. } \\
6.43\end{array}$} & \multirow[b]{2}{*}{5} & \multirow[b]{2}{*}{$5 / 0$} \\
\hline & & +++ & & & & ++ & & \\
\hline-26.36 & ++ & & ++ & ++ & & & 6 & $6 / 0$ \\
\hline-51.80 & & & ++ & & +++ & & 5 & $5 / 0$ \\
\hline Frec. & 2 & 3 & 4 & 2 & 3 & 2 & 16 & $16 / 0$ \\
\hline$[\mathrm{mM}]$ & & & & & & & \multicolumn{2}{|c|}{ Selection $\geq 3$} \\
\hline & \multicolumn{6}{|c|}{$\begin{array}{c}\text { Antioxidant capacity } \mu 2.780\left(1.998-3.656 \mathrm{mg} \text { trolox g }^{-1} \text { p.f. }\right) \mathrm{R}^{2} 0.7220 \mathrm{C} . \mathrm{V} . \\
8.03\end{array}$} & & \\
\hline 20.38 & ++ & +++ & & & & ++ & 7 & $7 / 0$ \\
\hline 12.60 & +++ & & ++ & & & & 5 & $5 / 0$ \\
\hline-35.00 & & & +++ & ++ & ++ & & 7 & $7 / 0$ \\
\hline Frec. & 5 & 3 & 5 & 2 & 2 & 2 & 19 & $19 / 0$ \\
\hline$[\mathrm{mM}]$ & & & & & & & \multicolumn{2}{|c|}{ Selection $\geq 4$} \\
\hline \multicolumn{7}{|c|}{ Summary } & \multicolumn{2}{|c|}{ Total prop. + / - } \\
\hline Subtotal & 38 & 29 & 32 & 13 & 35 & 12 & \multicolumn{2}{|c|}{159} \\
\hline Selection & $1 / 9$ & $0 / 9$ & $1 / 9$ & $1 / 9$ & $1 / 9$ & $0 / 9$ & \multicolumn{2}{|c|}{ Variables 1 / 9} \\
\hline Prop. +/- & $32 / 6$ & $27 / 2$ & $32 / 0$ & $13 / 0$ & $31 / 4$ & $10 / 2$ & \multicolumn{2}{|c|}{$145^{Z} / 14$} \\
\hline$[\mathrm{mM}]$ & 1.125 & 15.75 & 0.090 & & 0.720 & & \multicolumn{2}{|c|}{ Selec. $\geq 29(22)$} \\
\hline
\end{tabular}

${ }^{S}$ Simple mean factor levels; ${ }^{\mathrm{T}}$ Eigenvalues expressed as a percentage of the mean of the response variable; ${ }^{\mathrm{U}}$ Range in parentheses corresponds to the predicted values from the simple mean; ${ }^{\mathrm{V}}$ Each sign corresponds to multiples of 0.25 rounded to the nearest quarter; " linear regression response type L, quadratic $\mathrm{C}$ and factor interaction; ${ }^{\mathrm{X}} \mathrm{Optimal}$ value of the predicted factors and probability: significant ${ }^{*}(0.05 \leq \operatorname{Pr} \leq 0.01)$, highly significant ${ }^{* *}(\operatorname{Pr}<0.01)$, otherwise not significant; ${ }^{\mathrm{Y}}$ Total observed frequency for that variable, ${ }^{\mathrm{Z}}$ Total frequency for the set of variables, factors with a subtotal equal to or greater than $20 \%$ are selected while variables greater than or equal to $15 \%$ are selected 
Table S4. Selection factors, quality variables and bioactive compounds of apple, stored in a controlled atmosphere for 7 months and left on shelf for 9 days

\begin{tabular}{|c|c|c|c|c|c|c|c|c|}
\hline \multirow[b]{2}{*}{ Eigenvalues } & \multicolumn{6}{|c|}{ Factors / simple average $[\mathrm{mM}]$} & \multirow{2}{*}{\multicolumn{2}{|c|}{$\begin{array}{l}\text { Eigenvectors } \\
\text { Tot. Prop. }+/-\end{array}$}} \\
\hline & K $1.125^{\mathrm{S}}$ & Сa 15.75 & Co 0.090 & Mo 0.045 & SA 0.720 & $\mathrm{Mg} 0.045$ & & \\
\hline & \multicolumn{6}{|c|}{ Colour $^{\mathrm{U}} \mu 63.76(59.58-66.46 \%) \mathrm{R}^{2} 0.8019$ C.V. 4.15} & \multirow{3}{*}{\multicolumn{2}{|c|}{\begin{tabular}{l|r|}
$20^{Y}$ & $16 / 4$ \\
Selection $\geq 4$
\end{tabular}}} \\
\hline Frec. & $6^{\mathbb{W}}$ & 5 & 2 & 0 & 5 & 2 & & \\
\hline \multirow[t]{2}{*}[\mathrm{mM}]{} & & & & & & & & \\
\hline & \multicolumn{6}{|c|}{ Firmness $\mu 10.30\left(9.17-11.51 \mathrm{lb}^{2} \mathrm{in}^{2}\right) \mathrm{R}^{2} 0.9685$ C.V. 3.95} & & \\
\hline Frec. & 3 & 5 & 2 & 0 & 3 & 0 & 13 & $13 / 0$ \\
\hline \multirow[t]{2}{*}[\mathrm{mM}]{} & & & & & & & \multicolumn{2}{|c|}{ Selection $\geq 3$} \\
\hline & \multicolumn{6}{|c|}{ Total soluble solids $\mu 13.7$ (12.0 - 14.6 ${ }^{\circ}$ Brix $) \mathrm{R}^{2}$ 0.9629 C.V. 3.30} & & \\
\hline Frec. & 4 & 2 & 3 & 0 & 4 & 0 & 13 & $13 / 0$ \\
\hline \multirow[t]{2}{*}[\mathrm{mM}]{} & & & & & & & \multicolumn{2}{|c|}{ Selection $\geq 3$} \\
\hline & \multicolumn{6}{|c|}{ Titratable acidity $\mu 0.3532\left(0.3015-0.3953 \%\right.$ malic acid) $R^{2} 0.9710$ C.V. 4.95} & \multirow{3}{*}{\multicolumn{2}{|c|}{\begin{tabular}{|c|c|}
16 & $16 / 0$ \\
Selection $\geq 3$
\end{tabular}}} \\
\hline Frec. & 4 & 3 & 4 & 0 & 3 & 2 & & \\
\hline \multirow[t]{2}{*}[\mathrm{mM}]{} & & & & & & & & \\
\hline & \multicolumn{6}{|c|}{$\begin{array}{c}\text { Rel. Sugar Acidity } \mu 38.88\left(33.45-46.36^{\circ} \text { Brix / malic acid) } R^{2} 0.9436 \text { C.V. }\right. \\
7.15\end{array}$} & \\
\hline Frec. & 3 & 5 & 2 & 2 & 3 & 4 & 19 & $17 / 2$ \\
\hline \multirow[t]{2}{*}[\mathrm{mM}]{} & & & & & & & \multicolumn{2}{|c|}{ Selection $\geq 4$} \\
\hline & \multicolumn{6}{|c|}{ Juice density $\mu 2.15\left(1.81-2.64 \mathrm{~g} \mathrm{ml}^{-1}\right) \mathrm{R}^{2}$ 0.8788 C.V. 12.20} & & \\
\hline Frec. & 7 & 0 & 5 & 7 & 7 & 0 & 26 & $22 / 4$ \\
\hline \multirow[t]{2}{*}[\mathrm{mM}]{} & $1.696^{\mathrm{X}}$ & 14.62 & 0.078 & 0.064 & 0.205 & & \multicolumn{2}{|c|}{ Selection $\geq 5$} \\
\hline & \multicolumn{6}{|c|}{ Percentage of juice $\mu 87.64(78.08-95.10 \%) \mathrm{R}^{2}$ 0.9149 C.V. 4.44} & & \\
\hline Frec. & 4 & 3 & 5 & 0 & 5 & 0 & 17 & $13 / 4$ \\
\hline \multirow[t]{2}{*}[\mathrm{mM}]{} & & & & & & & \\
\hline & \multicolumn{6}{|c|}{$\begin{array}{c}\text { Total phenols } \mu 469.968\left(356.939-590.806 \mu \mathrm{g} g a l_{\text {acid gr }}{ }^{-1} \mathrm{p} . \mathrm{f}\right) \mathrm{R}^{2} 0.7977 \text { C.V. } \\
6.43\end{array}$} & \multicolumn{2}{|c|}{ Selection $\geq 3$} \\
\hline Frec. & 2 & 3 & 4 & 2 & 3 & 2 & 16 & $16 / 0$ \\
\hline \multirow[t]{2}{*}[\mathrm{mM}]{} & & & & & & & Select & $n \geq 3$ \\
\hline & Antioxic & t capacity $\mu$ & $80(1.998-$ & $656 \mathrm{mg}$ trol & $\mathrm{xg}^{-1}$ p.f.) $R^{2}$ & 7220 C.V. & & \\
\hline Frec. & 5 & 3 & 5 & 2 & 2 & 2 & 19 & $19 / 0$ \\
\hline$[\mathrm{mM}]$ & & & & & & & Selec & $n \geq 4$ \\
\hline & & & Summary & & & & Total & op. + / - \\
\hline Subtotal & 38 & 29 & 32 & 13 & 35 & 12 & & $\frac{1}{159}$ \\
\hline Selection & $1 / 9$ & $0 / 9$ & $1 / 9$ & $1 / 9$ & $1 / 9$ & $0 / 9$ & & oles $1 / 9$ \\
\hline Prop. +/- & $32 / 6$ & $27 / 2$ & $32 / 0$ & $13 / 0$ & $31 / 4$ & $10 / 2$ & & $z / 14$ \\
\hline$[\mathrm{mM}]$ & 1.125 & 15.75 & 0.090 & & 0.720 & & Sele & $\geq 29(22)$ \\
\hline
\end{tabular}

${ }^{S}$ Simple mean factor levels; ${ }^{U}$ Range in brackets corresponds to the predicted values from the simple mean; ${ }^{\mathbb{W}}$ linear regression response type $\mathrm{L}$, quadratic $\mathrm{C}$ and factor interaction; ${ }^{\mathrm{x}} \mathrm{Optimal}$ value of the predicted factors and probability: significant ${ }^{*}(0.05 \leq \operatorname{Pr} \leq 0.01)$, highly significant ${ }^{* *}(\operatorname{Pr}<0.01)$, otherwise not significant; ${ }^{\mathrm{T}}$ Total observed frequency for that variable, ${ }^{\mathrm{Z}}$ Total frequency for the set of variables, those factors with a subtotal equal or greater than $20 \%$ are selected while variables greater or equal to $15 \%$ are selected 
Table S5. Factors, fruit quality and bioactive compounds of apple, stored in a controlled atmosphere for 7 months and left on the shelf for 13 days

\begin{tabular}{|c|c|c|c|c|c|c|c|c|}
\hline \multirow[b]{2}{*}{ Eigenvalues } & \multicolumn{6}{|c|}{ Factors / simple average $[\mathrm{mM}]$} & \multirow{2}{*}{\multicolumn{2}{|c|}{$\begin{array}{l}\text { Eigenvectors } \\
\text { Tot. Prop. +/- }\end{array}$}} \\
\hline & $\mathrm{K} 1.125^{\mathrm{S}}$ & Ca 15.75 & Co 0.090 & Mo 0.045 & SA 0.720 & $\operatorname{Mg} 0.045$ & & \\
\hline & \multicolumn{6}{|c|}{ Colour $^{\mathrm{U}} \mu$ 66.71 (62.29- 69.48\%) R $\mathrm{R}^{2} 0.9195$ C.V. 2.69} & & \\
\hline $26.77^{\mathrm{T}}$ & & & & ++ & +++ & & 5 & $5 / 0$ \\
\hline 8.53 & $++^{\mathrm{V}}$ & & ++ & -.- & & & 7 & $4 / 3$ \\
\hline-25.20 & & ++++ & & & & & 4 & $4 / 0$ \\
\hline Frec. & $2^{\mathrm{W}}$ & 4 & 2 & 5 & 3 & 0 & $16^{Y}$ & $13 / 3$ \\
\hline \multirow[t]{2}{*}[\mathrm{mM}]{} & & & & & & & \multicolumn{2}{|c|}{ Selection $\geq 3$} \\
\hline & \multicolumn{6}{|c|}{ Firmness $\mu 10.05\left(8.87-11.38 \mathrm{lb}^{2}{ }^{2}\right) \mathrm{R}^{2} 0.9606$ C.V. 3.40} & & \\
\hline 27.54 & ++ & & ++ & & +++ & & 7 & $7 / 0$ \\
\hline 17.70 & +++ & & & -- & & & 5 & $3 / 2$ \\
\hline-25.30 & & +++ & & & & ++ & 5 & $5 / 0$ \\
\hline Frec. & 5 & 3 & 2 & $2 \mathrm{C}$ & 3 & 2 & 17 & $15 / 2$ \\
\hline \multirow[t]{2}{*}[\mathrm{mM}]{} & $1.285^{\mathrm{X}}$ & 13.24 & 0.123 & 0.052 & 1.196 & 0.043 & \multicolumn{2}{|c|}{ Selection $\geq 3$} \\
\hline & \multicolumn{6}{|c|}{ Total soluble solids $\mu 13.55\left(12.80-14.60^{\circ}\right.$ Brix $) \mathrm{R}^{2}$ 0.8751 C.V. 4.61} & & \\
\hline 27.29 & & & & & +++ & & 3 & $3 / 0$ \\
\hline 9.61 & ++++ & & & & & & 4 & $4 / 0$ \\
\hline-25.29 & & ++++ & & & & & 4 & $4 / 0$ \\
\hline Frec. & 4 & 4 & 0 & 0 & 3 & 0 & 11 & $11 / 0$ \\
\hline$[\mathrm{mM}]$ & & & & & & & \multicolumn{2}{|c|}{ Selection $\geq 2$} \\
\hline & \multicolumn{6}{|c|}{ Titratable acidity $\mu 0.3363(0.2747-0.3953 \%$ malic acid $) R^{2} 0.9981$ C.V.1.42 } & & \\
\hline 33.24 & & +++ & ++ & & & & 5 & $5 / 0$ \\
\hline-14.18 & ++ & & & $\ldots$ & & & 5 & $2 / 3$ \\
\hline-41.12 & ++ & & & & +++ & & 5 & $5 / 0$ \\
\hline Frec. & 4 & 3 & 2 & 3 & 3 & 0 & 15 & $12 / 3$ \\
\hline$[\mathrm{mM}]$ & & & & & & & \multicolumn{2}{|c|}{ Selection $\geq 3$} \\
\hline & \multicolumn{6}{|c|}{ 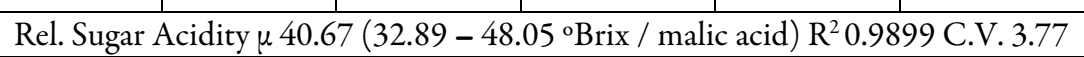 } & & \\
\hline 62.73 & ++ & & & & +++ & & 5 & $5 / 0$ \\
\hline 22.38 & +++ & & & $-\ldots$ & & & 6 & $3 / 3$ \\
\hline-52.04 & & +++ & & & & & 3 & $3 / 0$ \\
\hline Frec. & 5 & 3 & 0 & 3 & 3 & 0 & 14 & $11 / 3$ \\
\hline$[\mathrm{mM}]$ & & & & & & & \multicolumn{2}{|c|}{ Selection $\geq 3$} \\
\hline & \multicolumn{6}{|c|}{ Juice density $\mu 1.82\left(1.33-2.22 \mathrm{~g} \mathrm{ml}^{-1}\right) \mathrm{R}^{2} 0.9993$ C.V.1.17 } & & \\
\hline 38.16 & ++ & & & & +++ & & 5 & $5 / 0$ \\
\hline 18.43 & & & $\ldots$ & & & & 3 & $0 / 3$ \\
\hline-38.46 & -- & +++ & & & & & 5 & $3 / 2$ \\
\hline Frec. & 4 & 3 & 3 & 0 & 3 & 0 & 13 & $8 / 5$ \\
\hline$[\mathrm{mM}]$ & & & & & & & \multicolumn{2}{|c|}{ Selection $\geq 3$} \\
\hline & \multicolumn{6}{|c|}{ Percentage of juice $\mu 63.33(39.25-80.31 \%) \mathrm{R}^{2} 0.9555$ C.V. 11.74} & & \\
\hline 56.99 & & & ++ & ++ & ++ & & 6 & $6 / 0$ \\
\hline 17.84 & +++ & ++ & & -- & & & 7 & $5 / 2$ \\
\hline-53.91 & & ++++ & & & & & 4 & $4 / 0$ \\
\hline Frec. & 3 & 6 & 2 & 4 & 2 & 0 & 17 & $15 / 2$ \\
\hline$[\mathrm{mM}]$ & 1.175 & 15.00 & 0.098 & 0.049 & 0.816 & 0.046 & \multicolumn{2}{|c|}{ Selection $\geq 3$} \\
\hline & \multicolumn{6}{|c|}{$\begin{array}{c}\text { Total phenols } \mu 434.097 \text { (292.419- } 600.484 \mu \mathrm{g} \text { gal acid gr }{ }^{-1} \text { p.f) R } \mathrm{R}^{2} 0.8649 \text { C.V. } \\
6.17\end{array}$} & & \\
\hline
\end{tabular}




\begin{tabular}{|c|c|c|c|c|c|c|c|c|}
\hline 79.35 & --- & & ++ & & & & 5 & $2 / 3$ \\
\hline 40.43 & ++ & -- & ++ & & & ++ & 8 & $6 / 2$ \\
\hline-50.95 & & +++ & ++ & & & ++ & 7 & $7 / 0$ \\
\hline Frec & $\begin{array}{l}5 \mathrm{~L} \mathrm{C} ; \\
\mathrm{SA}^{\mathrm{W}}\end{array}$ & $\begin{array}{c}5 \mathrm{~L} \mathrm{C} ; \\
\mathrm{SA}\end{array}$ & $6 \mathrm{C}$ & 0 & $0 \mathrm{~L} \mathrm{C}$ & $4 \mathrm{LC}$ & 20 & $15 / 5$ \\
\hline$[\mathrm{mM}]$ & $0.383^{* * \mathrm{X}}$ & $10.24^{* *}$ & $0.130^{* *}$ & $0.051^{*}$ & $1.065^{* *}$ & $0.043^{* *}$ & \multicolumn{2}{|c|}{ Selection $\geq 4$} \\
\hline & \multicolumn{6}{|c|}{ Antioxidant capacity $\mu 3.261$ ( $1.528-4.633 \mathrm{mg}$ trolox $\mathrm{g}^{-1}$ p.f.) $\mathrm{R}^{2} 0.9512$ C.V. 5.19} & & \\
\hline 151.10 & & & ++ & & +++ & & 5 & $5 / 0$ \\
\hline 104.19 & ++++ & & & & & & 4 & $4 / 0$ \\
\hline-141.89 & & +++ & & & & ++ & 5 & $5 / 0$ \\
\hline Frec. & 4 & 3 & 2 & 0 & 3 & 2 & 14 & $14 / 0$ \\
\hline$[\mathrm{mM}]$ & & & & & & & \multicolumn{2}{|c|}{ Selection $\geq 3$} \\
\hline & \multicolumn{6}{|c|}{ Summary } & \multicolumn{2}{|c|}{ Tot. prop. +/- } \\
\hline Subtotal & 36 & 34 & 19 & 17 & 23 & 8 & \multicolumn{2}{|c|}{137} \\
\hline Selection & $3 / 9$ & $3 / 9$ & $1 / 9$ & $1 / 9$ & $1 / 9$ & $1 / 9$ & \multicolumn{2}{|c|}{ Variables 3/9 } \\
\hline Prop. +/- & $31 / 5$ & $32 / 2$ & $16 / 3$ & $4 / 13$ & $23 / 0$ & $8 / 0$ & \multicolumn{2}{|c|}{$114^{\mathrm{Z}} / 23$} \\
\hline$[\mathrm{mM}]$ & 1.285 & 15.00 & & & 1.196 & & \multicolumn{2}{|c|}{$\begin{array}{c}\text { Selec. } \geq 23 \\
(17)\end{array}$} \\
\hline
\end{tabular}

${ }^{S}$ Simple mean factor levels; ${ }^{\mathrm{T}}$ Eigenvalues expressed as a percentage of the mean of the response variable; ${ }^{\mathrm{R}}$ Range in parentheses corresponds to the predicted values from the simple mean; ${ }^{\mathrm{V}}$ Each sign corresponds to multiples of 0.25

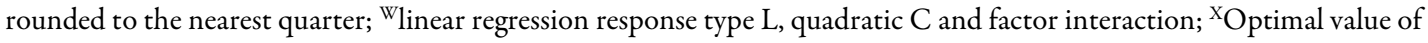
the predicted factors and probability: significant ${ }^{*}(0.05 \leq \operatorname{Pr} \leq 0.01)$, highly significant ${ }^{* *}(\operatorname{Pr}<0.01)$, otherwise not significant; ${ }^{\mathrm{Y}}$ Total observed frequency for that variable, ${ }^{\mathrm{Z}}$ Total frequency for the set of variables, factors with a subtotal equal to or greater than $20 \%$ are selected while variables greater than or equal to $15 \%$ are selected 
Table S6. Selection of factors, quality variables and bioactive compounds of apple, stored in a controlled atmosphere for 7 months and left on the shelf for 13 days

\begin{tabular}{|c|c|c|c|c|c|c|c|c|}
\hline \multirow[b]{2}{*}{ Eigenvalues } & \multicolumn{6}{|c|}{ Factors / simple average $[\mathrm{mM}]$} & \multirow{2}{*}{\multicolumn{2}{|c|}{$\begin{array}{l}\text { Eigenvectors } \\
\text { Tot. Prop. }+1\end{array}$}} \\
\hline & K $1.125^{S}$ & Ca 15.75 & Co 0.090 & Mo 0.045 & SA 0.720 & $\operatorname{Mg} 0.045$ & & \\
\hline & \multicolumn{6}{|c|}{ Colour $^{\mathrm{U}} \mu 66.71(62.29-69.48 \%) \mathrm{R}^{2} 0.9195$ C.V. 2.69} & & \\
\hline Frec. & $2^{\mathrm{W}}$ & 4 & 2 & 5 & 3 & 0 & $16^{\mathrm{Y}}$ & $13 / 3$ \\
\hline \multirow[t]{2}{*}[\mathrm{mM}]{} & & & & & & & \multicolumn{2}{|c|}{ Selection $\geq 3$} \\
\hline & \multicolumn{6}{|c|}{ Firmness $\mu 10.05\left(8.87-11.38 \mathrm{lb} \mathrm{in}^{2}\right) \mathrm{R}^{2} 0.9606$ C.V. 3.40} & & \\
\hline Frec. & 5 & 3 & 2 & $2 \mathrm{C}$ & 3 & 2 & 17 & $15 / 2$ \\
\hline$[\mathrm{mM}]$ & $1.285^{\mathrm{X}}$ & 13.24 & 0.123 & 0.052 & 1.196 & 0.043 & \multicolumn{2}{|c|}{ Selection $\geq 3$} \\
\hline & \multicolumn{6}{|c|}{ Total soluble solids $\mu 13.55$ (12.80 - 14.60 ${ }^{\circ}$ Brix) $\mathrm{R}^{2}$ 0.8751 C.V. 4.61} & & \\
\hline Frec. & 4 & 4 & 0 & 0 & 3 & 0 & \multirow{2}{*}{\multicolumn{2}{|c|}{\begin{tabular}{c|c}
11 & $11 / 0$ \\
Selection $\geq 2$
\end{tabular}}} \\
\hline$[\mathrm{mM}]$ & & & & & & & & \\
\hline & \multicolumn{6}{|c|}{ Titratable acidity $\mu 0.3363(0.2747-0.3953 \%$ malic acid $) \mathrm{R}^{2} 0.9981$ C.V.1.42 } & & \\
\hline Frec. & 4 & 3 & 2 & 3 & 3 & 0 & 15 & $12 / 3$ \\
\hline$[\mathrm{mM}]$ & & & & & & & \multicolumn{2}{|c|}{ Selection $\geq 3$} \\
\hline & \multicolumn{6}{|c|}{ Rel. Sugar Acidity $\mu 40.67$ (32.89 - $48.05^{\circ}$ Brix / malic acid) $R^{2} 0.9899$ C.V. 3.77} & & \\
\hline Frec. & 5 & 3 & 0 & 3 & 3 & 0 & 14 & $11 / 3$ \\
\hline$[\mathrm{mM}]$ & & & & & & & \multicolumn{2}{|c|}{ Selection $\geq 3$} \\
\hline & \multicolumn{6}{|c|}{ Juice density $\mu 1.82\left(1.33-2.22 \mathrm{~g} \mathrm{ml}^{-1}\right) \mathrm{R}^{2}$ 0.9993 C.V.1.17 } & & \\
\hline Frec. & 4 & 3 & 3 & 0 & 3 & 0 & 13 & $8 / 5$ \\
\hline$[\mathrm{mM}]$ & & & & & & & \multicolumn{2}{|c|}{ Selection $\geq 3$} \\
\hline & \multicolumn{6}{|c|}{ Percentage of juice $\mu 63.33(39.25-80.31 \%) R^{2} 0.9555$ C.V. 11.74} & & \\
\hline Frec. & 3 & 6 & 2 & 4 & 2 & 0 & 17 & $15 / 2$ \\
\hline$[\mathrm{mM}]$ & 1.175 & 15.00 & 0.098 & 0.049 & 0.816 & 0.046 & \multicolumn{2}{|c|}{ Selection $\geq 3$} \\
\hline & \multicolumn{6}{|c|}{$\begin{array}{c}\text { Total phenols } \mu 434.097\left(292.419-600.484 \mu \mathrm{g} \text { gal acid gr }{ }^{-1} \text { p.f) R } \mathrm{R}^{2} \text { 0.8649 C.V. }\right. \\
6.17\end{array}$} & & \\
\hline Frec & $\begin{array}{l}5 \mathrm{LC} ; \\
\mathrm{SA}^{\mathrm{W}}\end{array}$ & $5 \mathrm{~L} \mathrm{C}$; SA & $6 \mathrm{C}$ & 0 & $0 \mathrm{~L} \mathrm{C}$ & $4 \mathrm{LC}$ & 20 & $15 / 5$ \\
\hline$[\mathrm{mM}]$ & $0.383^{* * X}$ & $10.24^{* *}$ & $0.130^{* *}$ & $0.051^{*}$ & $1.065^{* *}$ & $0.043^{* *}$ & \multicolumn{2}{|c|}{ Selection $\geq 4$} \\
\hline & \multicolumn{6}{|c|}{ Antioxidant capacity $\mu 3.261\left(1.528-4.633 \mathrm{mg}\right.$ trolox $\mathrm{g}^{-1}$ p.f. $) \mathrm{R}^{2} 0.9512$ C.V. 5.19} & & \\
\hline Frec. & 4 & 3 & 2 & 0 & 3 & 2 & \multicolumn{2}{|c|}{\begin{tabular}{l|l}
14 & $14 / 0$
\end{tabular}} \\
\hline$[\mathrm{mM}]$ & & & & & & & \multicolumn{2}{|c|}{ Selection $\geq 3$} \\
\hline & \multicolumn{6}{|c|}{ Summary } & \multicolumn{2}{|c|}{ Tot. prop.+/- } \\
\hline Subtotal & 36 & 34 & 19 & 17 & 23 & 8 & & 137 \\
\hline Selection & $3 / 9$ & $3 / 9$ & $1 / 9$ & $1 / 9$ & $1 / 9$ & $1 / 9$ & \multicolumn{2}{|c|}{ Variables 3/9 } \\
\hline Prop. $+/-$ & $31 / 5$ & $32 / 2$ & $16 / 3$ & $4 / 13$ & $23 / 0$ & $8 / 0$ & \multicolumn{2}{|c|}{$114^{z} / 23$} \\
\hline$[\mathrm{mM}]$ & 1.285 & 15.00 & & & 1.196 & & \multicolumn{2}{|c|}{$\begin{array}{l}\text { Selec. } \geq 23 \\
(17)\end{array}$} \\
\hline
\end{tabular}

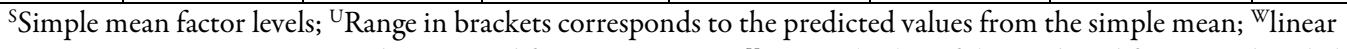
regression response type $\mathrm{L}$, quadratic $\mathrm{C}$ and factor interaction; ${ }^{\mathrm{x}} \mathrm{Optimal}$ value of the predicted factors and probability: significant ${ }^{*}(0.05 \leq \operatorname{Pr} \leq 0.01)$, highly significant ${ }^{* *}(\operatorname{Pr}<0.01)$, otherwise not significant; ${ }^{\mathrm{T}}$ Total observed frequency for that variable, ${ }^{\mathrm{Z}}$ Total frequency for the set of variables, those factors with a subtotal equal or greater than $20 \%$ are selected while variables greater or equal to $15 \%$ are selected 